\title{
EFFECT OF COBALT ON THE ENVIRONMENT AND LIVING ORGANISMS - A REVIEW
}

\author{
KOSIOREK, M. - WYSZKOWSKI, M." \\ Department of Environmental Chemistry, University of Warmia and Mazury in Olsztyn, Lódzki \\ Square 4, 10-727 Olsztyn, Poland \\ (phone: +48-89-523-3976) \\ *Corresponding author \\ e-mail: miroslaw.wyszkowski@uwm.edu.pl \\ (Received $18^{\text {th }}$ Apr 2019; accepted $12^{\text {th }}$ Jul 2019)
}

\begin{abstract}
This literature review presents a summary of papers related to the determination of the sources of cobalt compound presence in the environment and the resulting pollution of water and land. Their properties, determining their toxicity to living organisms, have been specified, with sections devoted to their effect on microorganisms and plants. The influence (negative and positive) of cobalt on living organisms in water and soil environments, including the biological balance of the soil (the number of microorganisms, enzymatic activity) and plant growth and development, and the possibilities of their use in the phyto- and bioremediation of areas polluted with cobalt have been described. Particular emphasis has been placed on the presentation of the effect of cobalt on animals and man.
\end{abstract}

Keywords: cobalt, contamination, environment, microorganisms, plants, animals, human

\section{Introduction}

Throughout history, human activity has contributed to environmental transformation. Over time, substantial population growth has significantly influenced the introduction of innovations in the world of technology which, in turn, have caused increasing interference of some processes in the environment (Guzmán-Morales et al., 2011). The development of industry, electric appliances, transport and the use of growing amounts of chemicals, mainly in the construction, chemical and agricultural sectors, has led to the appearance of different kinds of pollutants in the environment (Page and Feller, 2005; Murtaza et al., 2008; Dhaneesh et al., 2012; Wyszkowski and Sivitskaya, 2012; Modrzewska and Wyszkowski, 2014).

Heavy metals are the most common group of pollutants reducing the natural regeneration ability of the environment (Malik and Zeb, 2009; Mansouri et al., 2012). Many heavy metals are necessary for the proper functioning of living organisms. Some others, however, exert a negative effect on their development (Wyszkowska and Wyszkowski, 2002, 2003; Ciećko et al., 2005; Wyszkowski and Wyszkowska, 2009; Chmielowska-Bąk et al., 2014) and it should be remembered that the toxicity of a given chemical compound is determined by the dose introduced into the organism in a unit of time (Dhaneesh et al., 2012; Dobrowolski and Otto, 2012; Bezerra et al., 2014).

In environmental protection, the greatest focus is on such heavy metals as cadmium, lead and mercury, although other micronutrients also deserve attention due to the possibility of significant soil loading (Page and Feller, 2005). Among the elements present in amounts exceeding trace values in the soil, water, and air environments, cobalt (not yet fully known as a trace element) has attracted special attention (Fermoso et al., 2010). The diversified use of this metal in different branches of industry has caused growing demand in the world market (Lefebvre et al., 2008; Malik and Zeb, 
2009; Sytschev et al., 2009; Biswas et al., 2013; Huang et al., 2013). This contributed to the emergence of numerous companies involved in the production of this element. Production of cobalt by major companies worldwide in the recent years has been on a significant increase. The total production of cobalt by major companies in 2008 amounted to 28,901 tonnes (Elliot and Litzinger, 2015), while by 2015, it increased to 220000 tonnes (Sun et al., 2019).

With the growing demand for this raw material (Liu and Erhan, 2002; Pathak and Choppin, 2009; Fermoso et al., 2010; Banks et al., 2012; Hong et al., 2012; Esther et al., 2013) the problem of its excessive accumulation in the environment began to appear and also started to have a significant effect not only on plants (Akbar et al., 2013) and animal organisms, but also on humans (Balestrazzi et al., 2009; Koigoora et al., 2013; Devi et al., 2014).

The aim of this paper is to present the sources of cobalt occurrence in the natural environment and its effect on the functioning of selected groups of living organisms. The influence of cobalt on environment, living organisms in water and soil environments, including the biological balance of the soil (the number of microorganisms, enzymatic activity) and plant growth and development, animals and man was presented. The possibilities of use of microorganisms and plants in the phytoand bioremediation of areas polluted with cobalt have been described.

\section{Sources and forms of cobalt presence in the environment}

In the periodic table of elements, cobalt is classified as a transition metal (Koch et al., 2007). It has both chalcophile, siderophile and lithophile properties. Its chalcophility manifests itself mainly in the fact that it can occur in the form of sulfides in the lowest parts of the Earth's mantle (Lock et al., 2006), while cobalt siderophility is related to its low affinity to oxygen and sulfur, which makes this metal soluble in liquid nitrogen and able to occur in the Earth's core. Cobalt also occurs in the silicate layer of the Earth's crust, which indicates litophile properties. It is assumed that the natural cobalt content in the Earth's crust does not exceed $12 \mathrm{mg} \cdot \mathrm{kg}^{-1}$ (Sheppard et al., 2007). Alkaline igneous rocks are the largest cobalt accumulators. They contain up to $200 \mathrm{mg} \cdot \mathrm{kg}^{-1}$ of this element, while the same igneous rocks, but with an acidic character, contain no more than $15 \mathrm{mg} \cdot \mathrm{kg}^{-1}$. Small cobalt contents are also found in sedimentary rocks, where its concentration is highest in mudstones (around $20 \mathrm{mgkg}^{-1}$ ) and lowest in limestones (around $3 \mathrm{mg} \cdot \mathrm{kg}^{-1}$ ). Minerals are also a source of cobalt, which include CoAsS (cobaltite), $\mathrm{CoCO}_{3}$ (spherocobaltite), $\mathrm{Co}_{3} \mathrm{~S}_{4}$ (linnaeite), $\mathrm{Co}(\mathrm{Ni}) \mathrm{As}_{3}$ (smaltite) and $\mathrm{CoAs}_{2}$ (safflorite) (Luo et al., 2010). The contamination of soil with cobalt have the effect on other trace elements in soil, e.g. they may be increased the content of lead, chromium, nickel and zinc in soil (Kosiorek and Wyszkowski, 2019c).

Cobalt is released during the weathering process in the oxidation state of +2 and is then strongly bound by the mineral and organic-mineral complex in a readily- and slowly- exchangeable form (Swarnalatha et al., 2013). Due to ion exchange and chemical processes, cobalt is adsorbed by clay minerals, which results in the formation of complex compounds on their surface (Li et al., 2009). Special importance in this respect is attributed to montmorillonite, whose sorption capacity (also including for cobalt) is significantly higher than other clay minerals. The adsorption of this element by manganic minerals is also possible. The most frequent form of cobalt presence in the soil is $\mathrm{Co}^{2+}$ (ionic form), $\mathrm{Co}^{3+}$ (coordination compounds) as well as $\mathrm{CoOH}^{+}$ 
andCo(OH $)_{3}$. Moreover, small amounts of readily-soluble cobalt in the form of $\mathrm{Co}(\mathrm{OH}){ }_{2}{ }^{0}$ occur in the soil solution, whose amount compared to the total content is no higher than 5\%. Organic fertilization causes a small increase in the amounts of cobalt in a soluble form in the soil (Faucon et al., 2007). A naturally high soil cobalt level is closely linked to manganese and iron presence as well as organic soils. This is due to the high susceptibility of the oxides of these metals to binding and adsorbing the cations of divalent and trivalent cobalt, as well as easy sorption by organic matter (DávilaRangel and Solache-Ríos, 2006). It is assumed that loamy and alluvial soils have naturally high cobalt contents of up to $12 \mathrm{mg} \cdot \mathrm{kg}^{-1}$, and podsolic and silty soils have the lowest, with a mean cobalt content of only $5.5 \mathrm{mg} \cdot \mathrm{kg}^{-1}$. Compared to the average cobalt content in the world's soils, this value is not much higher than the lowest cobalt content in sandy and silty soils, where it is $8 \mathrm{mg} \cdot \mathrm{kg}^{-1}$. However, soils formed from bedrock with a high cobalt content can contain up to $500 \mathrm{mg} \cdot \mathrm{kg}^{-1}$ of this element (Tappero et al., 2007).

Cobalt mobility in soils is low (Fujikawa and Fukui, 2001; Edwards et al., 2012). It is assumed that over $95 \%$ of cobalt after prior introduction into the soil does not move and it remains in the soil down to a depth of around $5 \mathrm{~cm}$. Increasing the acidity and anaerobic soil conditions causes the cobalt mobility to increase (Narendrula et al., 2012). The main cause of this tendency is the inhibition of valence bonds with Fe and Mn. However, since divalent cobalt and manganese ions do not have strong complex formation abilities, the outer hydration shell is not destroyed during their binding (Lalah et al., 2009). The presence of cobalt in the form of chelates also contributes to increasing the soil mobility of this element. The main causes of increasing the soil cobalt content include improper fertilizer management (Saaltink et al., 2014), use of some pesticides (Defarge et al., 2018) as well as inappropriately-used sludge from municipal sewage treatment plants (Ebrahimi et al., 2009; Ben-Fredj et al., 2014; Li et al., 2014; Zupančič and Skobe, 2014). Application of different substances (e.g. manure, zeolite, calcium oxide) to soil reduced the content of cobalt and other trace elements in soil (Kosiorek and Wyszkowski, 2019c). These materials (especially manure) have a positive effect on the available forms of phosphorus, potassium and magnesium, total nitrogen and other properties of soil (Kosiorek and Wyszkowski, 2019b).

Significant importance is also attributed to cobalt compounds emitted to the air, mainly during the combustion of hard coal and petroleum, which are especially transferred to the soil environment during intensive precipitation (Biswas et al., 2013; Singh and Cameotra, 2013). The extraction of different kinds of raw materials, particularly metallic, also leads to soil pollution with this element (Narendrula et al., 2012; Huang et al., 2013). Transport also causes a rise in cobalt content in the environment (Kuoppamäki et al., 2014; Werkenthin et al., 2014).

In Poland, the soil cobalt content limits are set out in the Regulation of the Polish Minister of the Environment of 1 September (2016) on soil quality standards and land quality standards. For protected areas and land which is part of a protected area and in the surface soil layer (down to $30 \mathrm{~cm}$ ) of agricultural land, the permissible cobalt content should not be higher than $20-50 \mathrm{mg} \cdot \mathrm{kg}^{-1}$ of soil dry matter and in the soil layer in industrial areas, surface mining land in use and communication areas, it may not exceed $200 \mathrm{mg} \cdot \mathrm{kg}^{-1}$ of soil dry matter.

Both in surface waters and groundwaters, cobalt occurs in the oxidation state of +2 and +3 . Moreover, it can also occur in the form of complex compounds, which it forms with cyanides, ammonia and edetic and nitrilotriacetic acid, most often present in 
different kinds of detergents (Ghassabzadeh et al., 2010). The natural cobalt concentration in fresh surface waters does not exceed $0.2 \mu \mathrm{g} \cdot \mathrm{dm}^{-3}$ and in drinking water it is $0.03 \mu \mathrm{g} \cdot \mathrm{dm}^{-3}$. Salt groundwaters, compared to fresh waters, are characterized by its lowest natural content $-0.02 \mu \mathrm{g} \cdot \mathrm{dm}^{-3}$ (Qiu and Zheng, 2009). Cobalt solubility mainly depends on the $\mathrm{pH}$ of the water environment and on its concentration (Ochieng et al., 2009). The content of cobalt in surface waters is various (Table 1).

Due to rapid cobalt binding by organic matter, all kinds of clay minerals and iron and manganese in an oxide form, cobalt in an oxidized form does not persist very long in water. The result is substantial cobalt accumulation in the bottom sediments of both fresh and salt waters (Sukdeo et al., 2012; Ghandour et al., 2014), where its content in the sediments of flowing surface waters is around $13 \mathrm{mg} \cdot \mathrm{kg}^{-1}$. According to Jayasiri et al. (2014) the cobalt sedimentation rate is affected by climatic conditions and seasonal fluctuations (Mohiuddin et al., 2012). The mobility and solubility of this element in bottom sediments is determined mainly by its form (Wu et al., 2012) and sorption processes occurring between cobalt ions and negatively-charged sediment molecules (Jayasiri et al., 2014). As a result of changing physicochemical conditions, cobalt in sediments may be re-released to water (Sukdeo et al., 2012; Zamani-Hargalani et al., 2014).

Table 1. The content of cobalt in fresh and salty waters worldwide

\begin{tabular}{|c|c|c|}
\hline Place, country & Cobalt content in water & Source \\
\hline \multicolumn{3}{|c|}{ Rivers } \\
\hline Tsurumi, Yokohama, Japan & $14000-75000 \mu \mathrm{g} \cdot \mathrm{dm}^{-3}$ & Mohiuddin et al. (2012) \\
\hline Ramisi, Kenya & $3.70-8.30 \mu \mathrm{g} \cdot \mathrm{dm}^{-3}$ & Ochieng et al. (2009) \\
\hline Amazon, South America & $0.006-0.011 \mu \mathrm{g} \cdot \mathrm{dm}^{-3}$ & Yabuki et al. (2014) \\
\hline Ho Chi Minh City (Saigon), Vietnam & $1 \mu \mathrm{g} \cdot \mathrm{dm}^{-3}$ & Chanpiwat and Sthiannopkao (2014) \\
\hline \multicolumn{3}{|c|}{ Lakes } \\
\hline Respomuso, Pyrenees, Spain & $0.08 \mu \mathrm{g} \cdot \mathrm{dm}^{-3}$ & Zaharescu et al. (2009) \\
\hline Nasser, Egypt & $185 \mu \mathrm{g} \cdot \mathrm{dm}^{-3}$ & Rashed (2001) \\
\hline Malta, Poland & $10-20 \mu \mathrm{g} \cdot \mathrm{dm}^{-3}$ & Rzymski et al. (2014) \\
\hline Khanphur, Pakistan & $81-848 \mu \mathrm{g} \cdot \mathrm{dm}^{-3}$ & Iqbal et al. (2012) \\
\hline Kanyaboli, Kenya & $5.56-6.30 \mu \mathrm{g} \cdot \mathrm{dm}^{-3}$ & Ochieng et al. (2008) \\
\hline \multicolumn{3}{|c|}{ Sea } \\
\hline Red Sea, Jemen coast & $0.05-0.75 \mu \mathrm{g} \cdot \mathrm{dm}^{-3}$ & Al-Shiwafi et al. (2005) \\
\hline Baltic Sea, Poland & $0.45 \mu \mathrm{g} \cdot \mathrm{dm}^{-3}$ & Kabata-Pendias and Pendias (2001) \\
\hline
\end{tabular}

The metals and ceramic industries are most responsible for cobalt introduction into surface waters. Due to the wide-ranging application of this metal, particularly in the petrochemical, aviation or power industries, the amount of introduced wastewater with substantial cobalt contents has a negative effect not only on the condition of surface waters, but also on the condition of groundwaters (Wang et al., 2007; Abdel-Razek et al., 2009; Ebrahimi et al., 2009; Abd-Alla et al., 2014; Chanpiwat and Sthiannopkao, 2014). Additionally, pollutants also present in the air, which travel with waste to a given body of water (Mohiuddin et al., 2012; Sandergaard, 2013) and tourist activity (Koigoora et al., 2013) can contribute to this situation. In groundwaters, cobalt content depends mainly on the well location and on the water extraction technique. The main 
factors which can cause an increase in its content in groundwaters are: contamination of unconfined groundwaters from bedrocks containing the water-bearing layer (Obiri, 2007) and anthropogenic activities (Upadhyaya et al., 2014).

The permissible cobalt concentration for class I and II of uniform parts of surface waters is set out at $\leq 0.05 \mathrm{mg} \cdot \mathrm{dm}^{-3}$ (Regulation of the Polish Minister of the Environment of 21 July, 2016). The permissible cobalt concentration in groundwaters is: class I (very good) - $0.02 \mathrm{mg} \cdot \mathrm{dm}^{-3}$, class II (good) $-0.05 \mathrm{mg} \cdot \mathrm{dm}^{-3}$, class III (satisfactory) - $0.2 \mathrm{mg} \cdot \mathrm{dm}^{-3}$, class IV (unsatisfactory) - $1 \mathrm{mg} \cdot \mathrm{dm}^{-3}$, class $\mathrm{V}$ (poor) $>1 \mathrm{mg} \cdot \mathrm{dm}^{-3}$ (Regulation of the Polish Minister of the Environment of 21 December, 2015). Cobalt content in surface waters largely depends on the treated wastewater introduced into them. According to the Regulation of the Polish Minister of the Environment of 18 November (2014) the permitted cobalt concentration in treated wastewater from the ceramic industry should not be higher than $0.1 \mathrm{mg} \cdot \mathrm{dm}^{-3}$ and less than $1 \mathrm{mg} \cdot \mathrm{dm}^{-3}$ in the other wastewater types.

Apart from cobalt presence in soils and waters, this element is also in the air in an oxidized and insoluble form in dust (Pietrodangelo et al., 2014). Its natural content in the air is low. It is assumed that this value ranges from 0.0005 to $0.005 \mathrm{ng} \cdot \mathrm{dm}^{-3}$. Excessive levels of the natural cobalt air content are found only over urbanized areas (Albayrak and Mor, 2011; Canepari et al., 2014; Dos Anjos-Paulino et al., 2014). This relationship is presented in Table 2 which provides the contents of cobalt in the air in certain parts of the world.

Table 2. The content of cobalt in the air in selected places in the world

\begin{tabular}{c|c|c}
\hline Place, country & Cobalt content in air & Source \\
\hline Łódź, Poland & $0.31 \mathrm{ng} \cdot \mathrm{m}^{-3}$ & Bem et al. (2003) \\
Cap Ferrat, south-west coast of France & $0.10-0.28 \mathrm{ng} \cdot \mathrm{m}^{-3}$ & Heimbürger et al. (2010) \\
South-East Sea of Japan, Japan & $0.31-0.41 \mathrm{ng} \cdot \mathrm{m}^{-3}$ & Kang et al. (2009) \\
Milan, Italy & $2.10 \mathrm{ng} \cdot \mathrm{m}^{-3}$ & Rizzio et al. (2001) \\
Rio de Janeiro, Brazil & $0.40 \mathrm{ng} \cdot \mathrm{m}^{-3}$ & Miranda and Tomaz (2008) \\
Beijing, China & $7.90 \mathrm{ng} \cdot \mathrm{m}^{-3}$ & Wang et al. (2001) \\
Frankfurt am Main, Germany & $0.08 \mathrm{ng} \cdot \mathrm{m}^{-3}$ & Zereini et al. (2005) \\
\hline
\end{tabular}

The most frequent sources of air pollution with this element are hard coal-fired power plants and road transport (Mahapatra et al., 2013). An increased air cobalt content is caused by: wind erosion (Singh et al., 2013; Canepari et al., 2014), metal industry activity (Sheppard et al., 2007) and the presence of dust rising from storage sites for different kinds of stored waste and hydrothermal particles (Sheppard et al., 2007; Antony et al., 2011; Singh et al., 2013). Seasonal variation of a given area affects the air cobalt concentration (Canepari et al., 2014).

In Polish legislation, the permissible reference values for cobalt are contained in the Regulation of the Polish Minister of the Environment of 26 January (2010) on reference values for various substances in the air. The permissible reference value for cobalt, expressed as the sum of this metal and its compounds in $\mathrm{PM}_{10}$ dust, averaged for the time of $1 \mathrm{~h}$, is $5 \mu \mathrm{g} \mathrm{Co} \cdot \mathrm{dm}^{-3}$ and for the whole calendar year this value should not exceed $0.4 \mu \mathrm{g} \mathrm{Co} \cdot \mathrm{dm}^{-3}$. EU law sets out the average emission limit values for 10 heavy metals in total, including cobalt and its compounds (expressed as cobalt - Co) at 0.5 
$\mathrm{mgN} \cdot \mathrm{dm}^{-3}$ over a sampling period of a minimum of $30 \mathrm{~min}$ and a maximum of $8 \mathrm{~h}$ (Directive 2010/75/EU).

Cobalt also occurs in the natural environment in the form of the ${ }^{55} \mathrm{Co},{ }^{56} \mathrm{Co},{ }^{57} \mathrm{Co}$, ${ }^{58} \mathrm{Co},{ }^{60} \mathrm{Co}$ isotopes, resulting from human activity (Tappero et al., 2007; Antony et al., 2011). They are characterized by radioactive properties, due to which they can emit beta and gamma radiation to the environment. Beta and gamma particles are charged positively or uncharged, respectively. Their formation is the result of numerous nuclear reactions. The radioactive half-life of cobalt ranges from several dozen days to thousands of years (Mollah and Begum, 2001). Cobalt isotopes have very wide application. An example can be ${ }^{60} \mathrm{Co}$, which serves both for human radiotherapy and also for cold pasteurization of different seasonings and food products. Despite their positive use, cobalt isotopes are also a by-product of nuclear processes (Nagpal, 2004). Their negative environmental impact is associated with their high mobility, which mainly depends on the chelate effect of the radioactive cobalt compound and on its oxidation state. Its decomposition in the soil is a very long process and can be accelerated only by decay if it is organic pollution. In the water environment, radioactive cobalt occurs in the oxidation state of +2 and +3 (Tappero et al., 2007). Cobalt in the oxidation state of +3 is both stable and mobile in the water environment. Cobalt presence in a divalent form allows easier adsorption of free ions of this element on the surface of iron occurring in an oxide form. The cobalt(II) form is not as stable as cobalt(III), which is caused by the absence of ligands responsible for its persistence in water (Hau et al., 2008).

In Polish legislation, there are no set out radioactive cobalt limits and in international law the content limit for this form of cobalt present in surface waters is set out by USEPA (2000 after 56 FR 33121, Appendix B 000), where for ${ }^{57} \mathrm{Co}$ this level is $4870 \mathrm{pCi} \cdot \mathrm{dm}^{-3}$, for ${ }^{58} \mathrm{Co}-1590 \mathrm{pCi} \cdot \mathrm{dm}^{-3}$ and for ${ }^{60} \mathrm{Co}-218 \mathrm{pCi} \cdot \mathrm{dm}^{-3}$.

As it results from the review of the above literature, the main cause for the contamination of the environment with cobalt has become the development of civilisation, and the inextricably linked development of industry. The elevated contents of this element taken up from the soil, water or the air by living organisms have been introduced into the food chain, at the same time creating a risk to their lives and proper functioning (Fig. 1).

Cobalt is not biodegradable as after its introduction to the environment, it constantly circulates within it, with only its form being transformed. With the introduction of cobalt into higher and higher links of the food chain, however, the excessive accumulation thereof occurs. Therefore, it creates the greatest risk to the final link of the food chain, namely the human (Biesalski and Grimm, 2012).

\section{Effect of cobalt on microorganisms}

The soil is inhabited in the greatest numbers by viruses, bacteria, fungi, algae and protozoa. Due to organic matter decomposition, they expand their biomass and contribute to increasing humus in the soil. Proper microorganism development depends on different kinds of factors, such as: light, humidity, temperature or nutrient availability. Among the many compounds affecting the course of microbiological processes, special importance is attributed to trace elements, which include cobalt (Wang et al., 2007; Abdel-Razek et al., 2009; Hlima et al., 2012). Maintaining its optimal content in microorganism cells can assist metabolic processes or increase their 
content of vitamin $\mathrm{B}_{12}$ assisting growth processes (Marrero et al., 2007; Kun-Tai et al., 2008; Abskharon et al., 2010). As shown by the results of the study by Hlima et al. (2012), cobalt presence in xylose isomerase ensures the proper course of sugar metabolism in microorganisms. Cobalt is part of the coenzymes of the genus Rhizobium bacteria or the free-living Azotobacter bacteria responsible for binding nitrogen from the air (Rancelis et al., 2012) because vitamin $\mathrm{B}_{12}$ synthesis is necessary for the course of redox processes and nucleoprotein synthesis (Pulgarín et al., 2013; Abd-Alla et al., 2014).

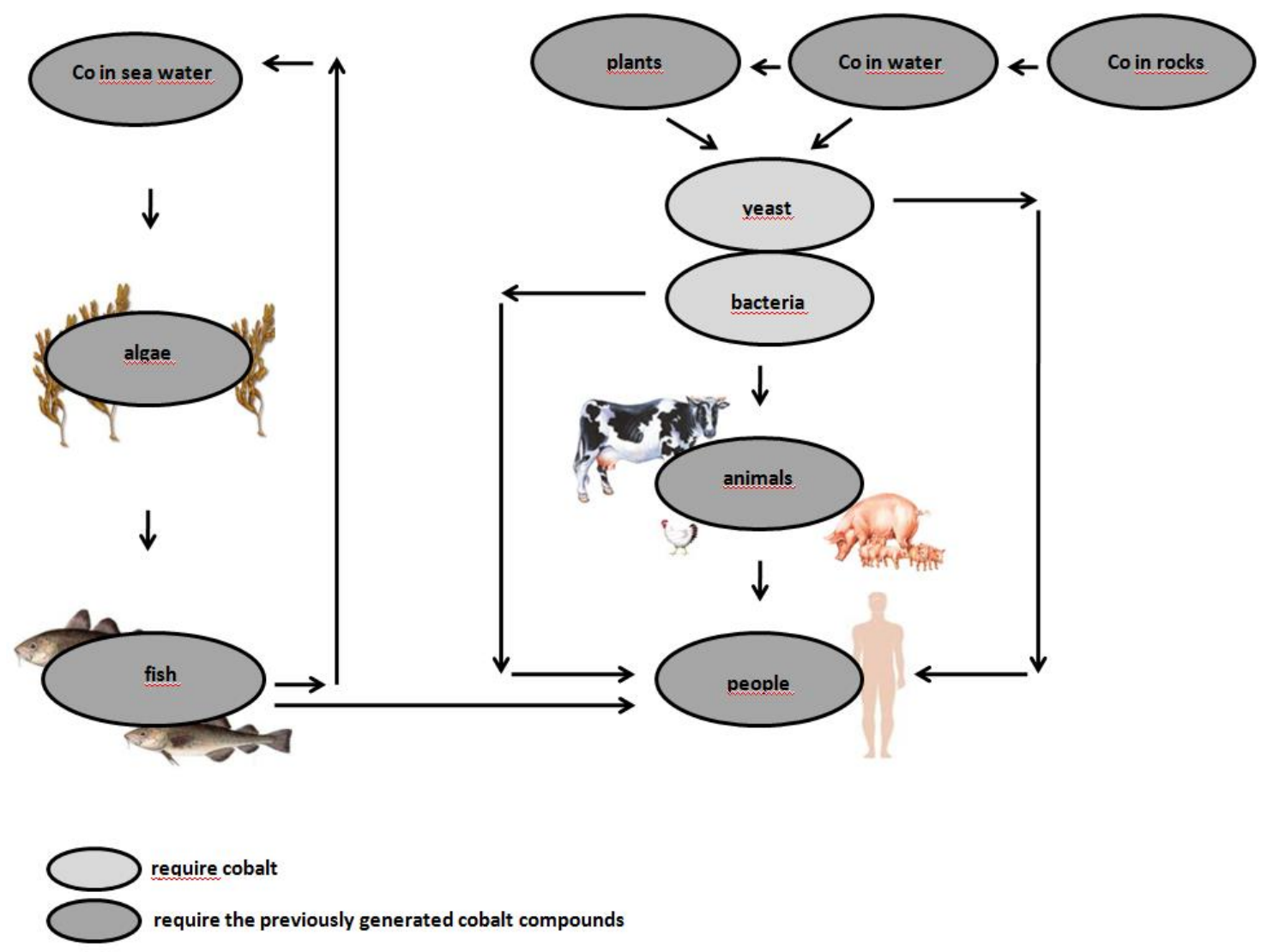

Figure 1. Cobalt cycle in the environment. (Source: own work based on Biesalski and Grimm, 2012)

Proper cobalt content in microorganisms is also important due to the initiation of many enzymatic reactions (Minamihata et al., 2012; Elleuche et al., 2014), protein absorption and decomposition (Antony et al., 2011). This is particularly visible for papilionaceous plants, due to their symbiosis with nodule bacteria. In these bacteria, cobalt is the activator of the urease enzyme, which is the catalyst in the urea decomposition reaction (Witte et al., 2002). Apart from carbon dioxide and water, the main product of this reaction is ammonia, which is also the final product of ammonification and enables the initiation of nitrification, where this compound will be oxidized to nitrites and nitrates (Guo et al., 2014). Nitrification is one of the major processes characterizing soil quality. Cobalt has a crucial effect on nitrification rate, but its excessive content in the soil may inhibit the process (Wyszkowska et al., 2006). In a study by Wyszkowska et al. (2006) in soil with a neutral reaction, this process was 
inhibited to a small degree by cobalt, applied at a lower dose (200 $\mathrm{mg} \cdot \mathrm{kg}^{-1}$ soil), regardless of the testing date. Under a higher cobalt dose (400 $\mathrm{mg} \cdot \mathrm{kg}^{-1}$ soil), nitrification decreased twofold-threefold. This adverse effect disappeared completely on the $60^{\text {th }}$ day of soil incubation. An excessive soil cobalt content may cause a decrease in the mineral nitrogen content $\left(\mathrm{N}-\mathrm{NH}_{4}{ }^{+}+\mathrm{N}-\mathrm{NO}_{3}{ }^{-}\right)$. According to Welp (1999) cobalt acts more weakly in the soil than other heavy metals on the activity of dehydrogenases: $\mathrm{Hg}>\mathrm{Cu}>\mathrm{Cr}^{6+}>\mathrm{Cr}^{3+}>\mathrm{Cd}^{2+}>\mathrm{Ni}^{2+}>\mathrm{Zn}^{2+}>\mathrm{As}^{3+}>\mathrm{Co}^{2+}>\mathrm{Pb}^{2+}$ and, in the view of Nowak et al. (2003) also on the activity of acid phosphatase: $\mathrm{Cu}^{2+}>\mathrm{Al}^{3+}>\mathrm{Cd}^{2+}>\mathrm{Zn}^{2+}>\mathrm{Fe}^{3+}>\mathrm{Ni}^{2+}>\mathrm{Pb}^{2+}>\mathrm{Sn}^{2+}>\mathrm{Fe}^{2+}>\mathrm{Co}^{2+}$ and alkaline phosphatase: $\mathrm{Cd}^{2+}>\mathrm{Al}^{3+}>\mathrm{Zn}^{2+}>\mathrm{Fe}^{3+}>\mathrm{Cu}^{2+}>\mathrm{Pb}^{2+}>\mathrm{Ni}^{2+}>\mathrm{Fe}^{2+}>\mathrm{Se}^{2+}>\mathrm{Co}^{2+}$.

According to Wang et al. (2010) cobalt has an average effect on soil microorganisms in the heavy metal toxicity series $(\mathrm{Cr}>\mathrm{Pb}>\mathrm{As}>\mathrm{Co}>\mathrm{Zn}>\mathrm{Cd}>\mathrm{Cu})$. Exceeding the threshold levels may, however, have a negative effect on the proper course of life processes (Maguire and Collins, 2001). The result may be disturbance of the course of redox reactions, inhibition of biopolymer hydrolysis processes or the slowing of enzymatichydrolysis (Abd-Alla et al., 2014; Hu et al., 2014). Radicals and unstable products of enzymatic reactions, causing cell growth, begin to appear in these organisms. The cell wall bursts as a result of increased osmotic pressure. Another result of an excessive cobalt content in microorganism cells may be the inhibition or acceleration of cell division (Antony et al., 2011).

Apart from microorganisms reacting negatively to high cobalt doses, there are also those which have the ability to remove it. The reduced cobalt harmfulness to these organisms is the result of their having cell systems affecting accumulation, excretion or enzymatic changes, which can reduce its harmfulness (Hoffman et al., 2010). There are also typically specialized groups of microorganisms with specific regenerative abilities enabling the accumulation of excessive cobalt amounts from the soil (Peca et al., 2008; Abskharon et al., 2010).

The analyzed literature shows that a high ability to remove cobalt from the soil characterizes such bacteria as: Pseudomonas denitrificans (Rong et al., 2008), Pectobacterium antrosepticum (Elleuche et al., 2014), Escherichia coli (Freeman et al., 2005), Cellulosimicrobium cellulans and yeasts: Schizosaccharomyces pombe or Saccharomyces cerevisiae (Ruta et al., 2010; Ryuko et al., 2012). Organisms more sensitive to increased cobalt contents include, among others, the bacteria Rhizobium tibeticum (Abd-Alla et al., 2014) or Serratia marcescens (Marrero et al., 2007). Harmful effects are also visible in fungi, for example, Aspergillus oryzae and Aspergillus niger (Biswas et al., 2013; Li et al., 2014). Abdel-Razek et al. (2009) also found a high resistance of some fungi from the genera Paecilomyces, Rhizopus, Penicillium, Trichoderma and Pythium to excessive cobalt contents. Wang et al. (2007) confirmed the negative effects of cobalt on nematodes (Caenorhabditis elegans). Earthworms are also at risk due to the accumulation of the part of cobalt which is not excreted (Ashfaq et al., 2009).

Some groups of microorganisms, due to the production of biosurfactants, have the ability to remove cobalt. They mainly include bacteria, fungi and yeasts. One of the many microorganisms able to produce surface active agents in the form of lipopeptides is the bacterium Bacillus subtilis. Singh and Cameotra (2013) report that the ability to remove cobalt resulting from the application of this biosurfactant is over $35 \%$.

Maintaining proper growth conditions for a given group of microorganisms to increase pollutant removal efficiency also has a special effect on the initiation of the 
above processes (Abdel-Razek et al., 2009). According to Amir and Pineau (2003) acceleration of cobalt cleanup from the soil by heterotrophic bacteria can be affected by a slightly acid soil reaction. Maintaining the $\mathrm{pH}$ at this level creates ideal conditions for faster release of this element in the soil, due to which it becomes more available to these microorganisms. Cobalt biosorption rate is also affected by the ambient temperature at which microorganisms live (Biswas et al., 2013). The higher it is, the more efficient this process is. This relationship was also confirmed by Abdel-Razek et al. (2009) who found raising the temperature by $10{ }^{\circ} \mathrm{C}$ led to an increase in cobalt accumulation by around $10 \%$. Soil microorganisms are also able to remove radioactive cobalt, which is confirmed by Sassman et al. (2007).

Cobalt is also present in salt and fresh surface waters and in groundwaters. Its proper amount, not exceeding the limit values, is necessary for the course of growth processes in water microorganisms, as well as for soil microorganisms (Elleuche et al., 2014). Microorganisms present in water are also able to reduce cobalt content under conditions of its excessive accumulation (Amir and Pineau, 2003). These processes include extracellular secretion, biotransformation and intracellular absorption and its precipitation outside the cleaning organism. Apart from naturally-occurring water microorganisms able to absorb cobalt, there are also those which are characterized by a higher biosorptive ability. Bacteria present in sea water can also contribute to cobalt content reduction (Amir and Pineau, 2003; Antony et al., 2011). These organisms include, among others, Cunninghamella elegans (Abdel-Razek et al., 2009) as well as Shewanella, which reduces the pollution of waters with radioactive cobalt (Hau et al., 2008).

\section{Effect of cobalt on plants}

Cobalt is the trace element which have a strong effect on growth and development of plants. The negative effect of soil contamination with cobalt on plants depends on many other factors e.g. soil reaction, content of organic matter, clay and other macronutrients and micronutrients in soil. The result of cobalt presence in the soil is its accumulation in plants, also including in their fruits (Soylak et al., 2013). It is absorbed by plant roots in the form of a cation in the oxidation state of +2 and chelate compounds (Karuppanapandian and Kim, 2013). Cobalt availability to plants largely depends on the soil conditions (Jonnalagadda et al., 2008; Agbenin et al., 2009; Wendling et al., 2009). This was confirmed in a study by Edwards et al. (2012) where the application of drainage in pasture soil accelerated the weathering of minerals and increased cobalt absorption by grasses. The accumulation rate for aquatic plants mainly depends on such factors as temperature, salinity and water oxygen concentration (Chatterjee and Dube, 2005). The necessity of cobalt for marine flora was confirmed by Antony et al. (2011) in a study conducted on marine phytoplankton.

Because of the cobalt presence in the coenzyme of nodule bacteria, it plays a significant role in papilionaceous plants (Tappero et al., 2007; Collins and Kinsela, 2011). Due to flavonoid secretion by plant roots, gene expression by genus Rhizobium microorganisms is induced. The genes encoding enzymes in nodules cause the infection of root hairs and then the formation of nitrogen-binding nodules. This is also the reason for the presence of substantial cobalt contents in these plants (Abd-Alla et al., 2014). Cobalt presence in plants also allows the proper course of metabolic and growth processes to be maintained (Page and Feller, 2005; Ashraf and Mian, 2008; Rong et al., 
2008; Collins and Kinsela, 2011; Soylak et al., 2012). According to Trejo-Tapia et al. (2001) cobalt content in plants has a positive effect on the production of betalains and secondary metabolites and cobalt is also responsible for leaf pigmentation in leguminous plants (Rancelis et al., 2012). It also plays a significant role during ethylene synthesis inhibition in sunflower, which was confirmed by Benlloch-González et al. (2010). Additionally, it serves as a catalyst in many enzymatic processes (Tappero et al., 2007; Dong Cho et al., 2012; Karuppanapandian and Kim, 2013).

Cobalt content varies depending on plant organ type. Murtaza et al. (2008) found that this content is higher in leaves than in the other parts of vegetables. This was also confirmed in a study by Chatterjee and Dube (2005) where cobalt was accumulated in greater amounts in the aboveground parts of cauliflower and cabbage than in their roots. For cereals, as Page and Feller (2005) reported that a similar tendency was obtained in wheat, but younger leaves have a much higher requirement for this element than older ones.

Cobalt toxicity is closely related with the acidity of the soil. In alkaline soil the toxic effect of cobalt contamination on plant development is smaller than in acid soil. For higher plants, no effect of cobalt on their growth and development has been shown (Tappero et al., 2007; Rancelis et al., 2012; Rognerud et al., 2013). However, to meet the nutritional requirements, cobalt content in their tissues should not be lower than $0.08 \mathrm{mg} / \mathrm{kg}$. Among papilionaceous plants, clovers have the greatest accumulative abilities and among cereals, wheats have the highest. In vegetables, cabbage and lettuce are characterized by the highest cobalt contents (Nirmal-Kumar et al., 2007). Application of different sorbents to soil (e.g. manure, calcium oxide, etc.) is effective in reducing the negative effect of contamination of cobalt on plants (Figs. 2 and 3). They reduced the content of cobalt and its bioconcentration and translocation in plants.

As a result of exceeding the limit values for cobalt, iron assimilability is blocked, which causes the appearance of toxic symptoms (Chatterjee and Chatterjee, 2002; Tappero et al., 2007). Increased cobalt contents in plants can cause disturbances of physiological, biochemical and metabolic processes (Wendling et al., 2009). According to Abd-Alla et al. (2014) these contents can also contribute to stopping the growth of nodules on the roots of papilionaceous plants and thus reduce their nitrogen assimilability (Jain and Nainawatee, 2000). The consequence of exceeding the permissible dose in plants is stopping growth processes and the appearance of disease symptoms, such as chlorosis, necrosis or tissue death (Chatterjee and Chatterjee, 2002; Chatterjee and Dube, 2005; Wyszkowski et al., 2009). Photosynthesis is disturbed, the intercellular spaces become smaller and the chloroplast structure disintegrates (Chatterjee and Chatterjee, 2002; Chaudhari et al., 2017).

These disturbances can also delay the maturation of flowers which, in turn, reduces their productivity and decreases plant yield significantly (Keeling et al., 2003; Chatterjee et al., 2006; Wyszkowski and Wyszkowska, 2007; Chaudhari et al., 2017; Muthaura et al., 2017; Jadoon and Malik, 2018). Moreover, much lower amounts of poor quality seeds are produced and the production of sugars, protein or starch deteriorates considerably. Some enzymes, such as peroxidase or acid phosphatase, increase their activity (Chatterjee et al., 2006). The plants growth on soil with the highest contamination of cobalt was halted, because water and nutrients uptake from soil by plants is decreased. 


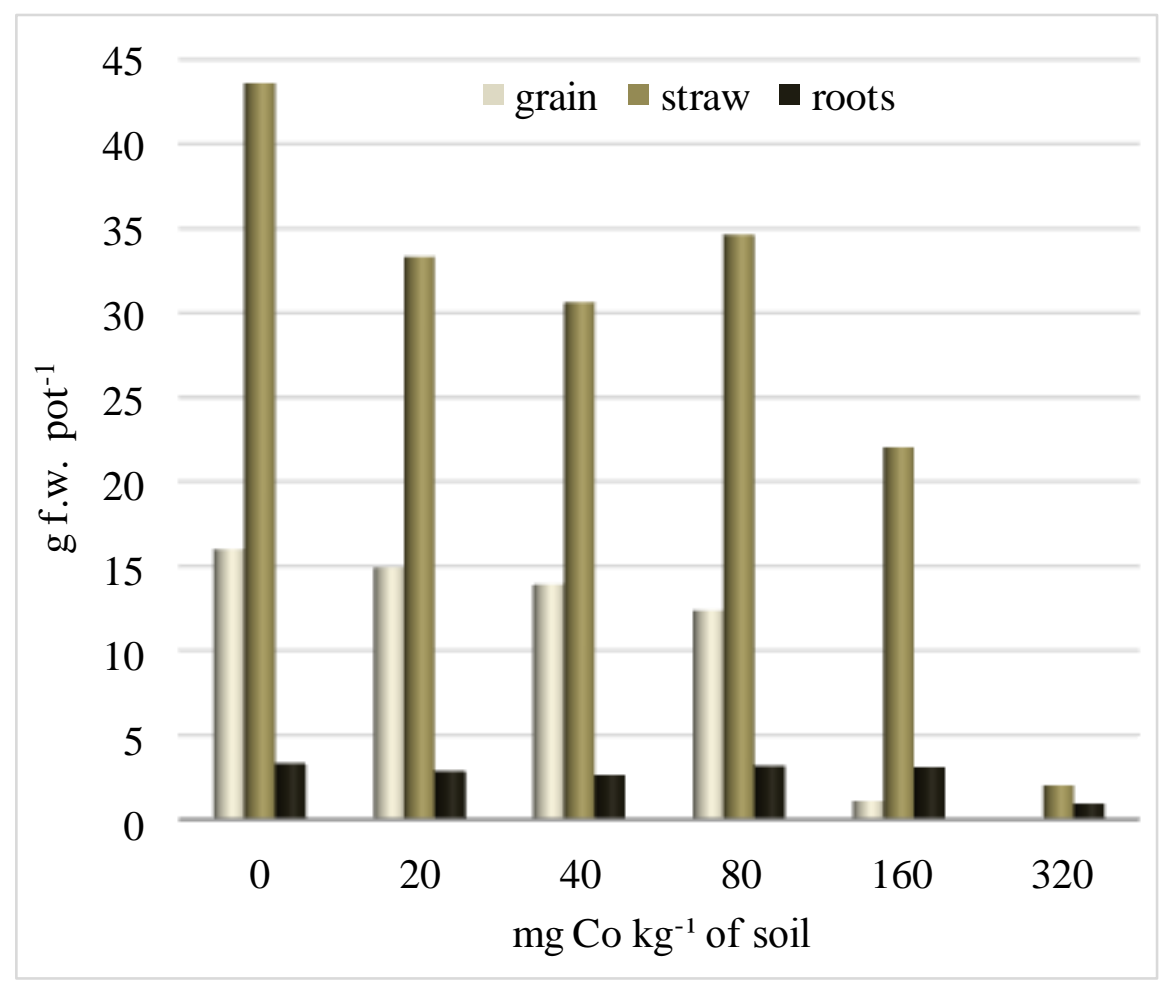

Figure 2. Effect of cobalt contamination on oats mass

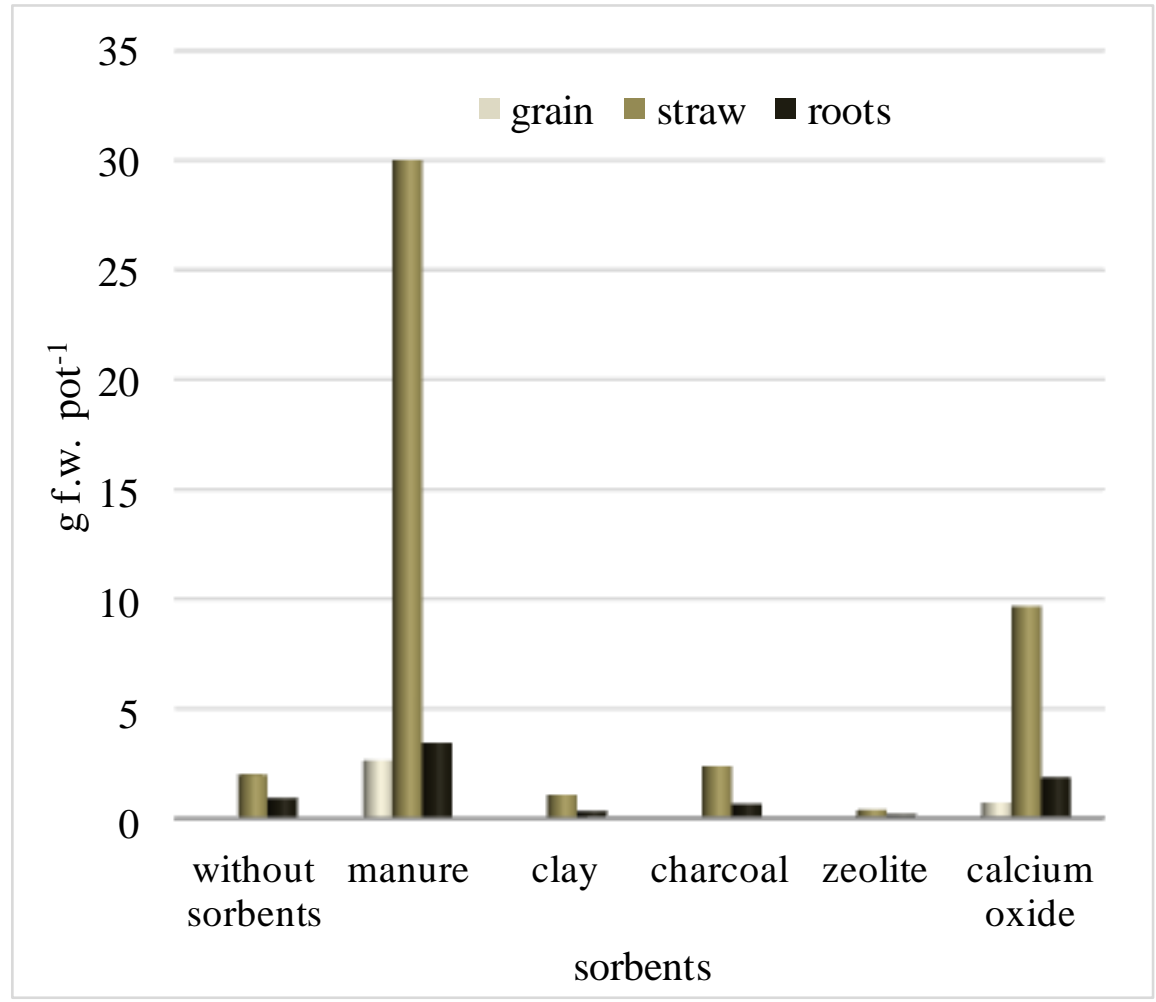

Figure 3. Effect of sorbents on oats mass in objects contaminated with $320 \mathrm{mg} \mathrm{Co} \mathrm{kg}^{-1}$ of soil 
Apart from the above plants, there are also those which do not show symptoms of toxicity associated with excessive cobalt accumulation (McLeod and Ciravolo, 2007). Cobalt content can range in them from 1.000 to even $50.000 \mathrm{mg} \cdot \mathrm{kg}^{-1}$ (Faucon et al., 2009). Examples of such plants are: Alyssum murale, Alyssum corsicum (Collins and Kinsela, 2011), Bulbostylis pseudoperennis (Saad et al., 2012), Crepidorhopalon perennis, Crepidorhopalon tenuis (Faucon et al., 2009), Nyssa sylvatica (Kukier et al., 2004; Chatterjee et al., 2006; McLeod and Ciravolo, 2007; Tappero et al., 2007; Van der Ent et al., 2013), Sopubia neptunii, Crotalaria cobalticola (Saad et al., 2012), Lemna minor (Hu et al., 2019).

Both terrestrial and aquatic plants have these abilities (Chatterjee and Dube, 2005). Cobalt presence in the tissues of these plants, called hyperaccumulators, mainly depends on soil, water and air pollution (Guzman-Morales et al., 2011; Saad et al., 2012; Cheruiyot et al., 2013). The soil pH also has a significant effect: the lower it is, the higher the cobalt absorption is by the plants (Tappero et al., 2007; Collins and Kinsela, 2011).

Cobalt accumulation in hyperaccumulators is different in every plant organ. According to Kukier et al. (2004) and Tappero et al. (2007) cobalt contents are much higher in aboveground parts than in roots, but over time this content increases. Such a tendency was confirmed by Tappero et al. (2007) who observed much higher cobalt content in older leaves of Alyssum murale than in younger ones. McLeod and Ciravolo (2007) on Nyssa sylvatica and Nyssa aquatica shows the opposite tendency. The highest cobalt concentration is observed near leaf margins, close to leaf trichomes. Apart from the cobalt presence in leaf tissues, it can also be adsorbed on its surface. The soil contamination with cobalt increased the content of this trace element in plants and the translocation coefficient and decreased the coefficients of the bioconcentration and transfer (Kosiorek and Wyszkowski, 2019d). The stress of cobalt increased the production of some amino and organic acids (Hu et al., 2019). The increased cobalt content in the plants characterized by high abilities for its accumulation usually causes them to have lower amounts of nutrients, such as calcium, potassium or magnesium (Faucon et al., 2009). These plants also have limited water absorption ability (Karuppanapandian and Kim, 2013).

An excessive soil cobalt content, apart from reducing plant growth and development, can affect the absorption of other elements by plants. In a study by Wyszkowski et al. (2009) soil contamination with cobalt caused a decrease content of potassium, phosphorus, sodium, magnesium and especially calcium in the aboveground parts of oats. In another experiment by Wyszkowski and Wyszkowska (2007) low cobalt doses (10-20 mg Co $\cdot \mathrm{kg}^{-1}$ soil) had a small effect on macronutrient content in spring barley. Its very high doses (320 mg Co $\mathrm{kg}^{-1}$ soil) caused increased contents of all macronutrients, especially calcium, sodium and nitrogen, in the aboveground parts of this plant. In experiment by Kosiorek and Wyszkowski (2019a) the contamination of soil with cobalt increased the concentration of nitrogen, phosphorus, sodium, calcium in all organs of oat (grain, straw and roots). Chatterjee and Chatterjee (2003) point out a high increase in phosphorus content and Gopal et al. (2003) a decrease in phosphorus and protein and non-protein nitrogen in plants under the influence of cobalt. 


\section{Effect of cobalt on animals}

Cobalt is included among elements commonly present in the cells of animal organisms. Its content depends on the feed type consumed by a given animal and on the state of environmental pollution at the place where it lives (Söyüt and Beydemir, 2011). Vitamin $\mathrm{B}_{12}$ and cyanocobalamin is the most frequent form of cobalt presence inside the body of animals, both terrestrial and aquatic. Cobalt content in these compounds is over $6 \%$. The presence of vitamin $\mathrm{B}_{12}$ enables the regulation of erythrocyte production as well as of the metabolism of proteins and nucleic acids (Stangl et al., 2000; Antony et al., 2011). This compound also participates in many enzymatic redox processes as the activator. Only those microorganisms that live in the soil, water environment and in an animal's alimentary tract are capable of its synthesis (Mukherjee and Kaviraj, 2011).

The effect of cobalt on aquatic animals is particularly important due to assisting enzymatic and metabolic processes (Mukherjee and Kaviraj, 2011; Söyüt and Beydemir, 2011). It is absorbed via the respiratory tract, adsorption or as a result of the consumption of vegetable and animal food (Klavins et al., 2009; Malik and Zeb, 2009; Dhaneesh et al., 2012; De Jesus et al., 2014). Cobalt absorption depends on many environmental factors. The state of water environment pollution and the amount of organic matter in a given body of water are included among them most often (Malik and Zeb, 2009). According to Klavins et al. (2009) cobalt accumulation in aquatic animal organs is lower with a higher organic matter content in the water habitat. Numerous studies by researchers (Klavins et al., 2009; Malik and Zeb, 2009; Waheed et al., 2014) also confirm the effect of differences in the age, sex, species and diet of aquatic animals on cobalt assimilation.

Increased cobalt absorption by aquatic animals is also affected by the amount of mobile forms of this element accumulated in the bottom sediments of lakes, rivers and seas (Mohiuddin et al., 2012; Rognerud et al., 2013; Swarnalatha et al., 2013; Jayasiri et al., 2014; Ramani et al., 2014). A particular risk to these animals is posed by sediments near highly populated places or places impacted by different industry branches and on the edge of water bodies (Swarnalatha et al., 2013; Chanpiwat and Sthiannopkao, 2014; Ghandour et al., 2014; Rzymski et al., 2014). A change in physicochemical water conditions is an additional factor causing increased cobalt release to waters (Ochieng et al., 2008; Sukdeo et al., 2012; Wu et al., 2012; Hierro et al., 2014; Zamani-Hargalani et al., 2014). The state of the pollution of coral reefs, which, apart from being a refuge for many animals, accumulate substantial amounts of pollutants, is also included among these factors (Koigoora et al., 2013; Briand et al., 2014). Studies by Malik and Zeb (2009), Chanpiwat and Sthiannopkao (2014) and Jayasiri et al. (2014) also include seasonality, which leads to changes in water parameters.

A high cobalt concentration, both in fresh and salt waters, leads to its excessive accumulation in the internal organs of the animals inhabiting them (Söyüt and Beydemir, 2011; Iqbal et al., 2012). Fish are the most studied aquatic animals in waters polluted with heavy metals, including cobalt. According to De Jesus et al. (2014) and Waheed et al. (2014) cobalt accumulates mainly in the inedible fish parts, which include gills, intestines, kidneys and liver. This was also confirmed by Klavins et al. (2009) and Türkmen et al. (2011). According to Malik and Zeb (2009) among the organs listed above, liver and kidneys stand out for their high abilities for the accumulation and detoxification of this metal. Cobalt also accumulates in the edible parts, such as flesh or skin, with its content much lower than in the above-listed organs (Malik and Zeb, 2009; Schmitt et al., 2009; Tepe, 2009). Waheed et al. (2014) found that cobalt content is 
higher in the muscles and gills of herbivorous fish than in carnivorous fish. Cobalt accumulation in fish organs leads to changes in the course of genetic, cytological or metabolic processes which are the cause of many diseases (Rzymski et al., 2014). Cobalt also affects the other animals inhabiting aquatic ecosystems, which was confirmed by many studies (Cavet et al., 2003; Türkmen et al., 2011; Lavoie et al., 2012; Abdallah, 2013; Alquezar and Anastasi, 2013; Holland et al., 2013; Sandergaard, 2013) where a high cobalt content was recorded in bivalves, shrimps, blue-green algae and algae inhabiting fresh waters. For salt bodies, excessively high cobalt doses showed a negative effect on scorpions, blue-green algae and sponges (Padovan et al., 2012; Alquezar and Anastasi, 2013; Batista et al., 2014).

High cobalt amounts accumulate in the successive links of the food chain, which are terrestrial and aerial animals (Klavins et al., 2009; Malik and Zeb, 2009; Albayrak and Mor, 2011; Söyüt and Beydemir, 2011; Mansouri et al., 2012; Sandergaard, 2013). In the body of terrestrial animals, cobalt is important due to its participation in the formation of vitamin $B_{12}$ (Stangl et al., 2000). In ruminants, it is produced in the rumen (Agbenin, 2002; Tiffany and Spears, 2005; Bishehsari et al., 2010) and the amount of this vitamin is highest in muscles, liver, kidneys and the heart. Animal products such as eggs, cheeses or milk can also contain substantial amounts of cobalt (Tiffany and Spears, 2005).

Cobalt content within the optimal amount is necessary for the course of proper life processes in every organism living on land. The youngest animals have the highest requirement for this element (Kadim et al., 2006; Ceacero et al., 2009). Older animals have a lower cobalt requirement, but its content rises over time as a result of accumulation. Cobalt also plays an important role as the catalyst of many enzymatic processes (Swarup et al., 2006). Kadim et al. (2006) found that the injection of $350 \mathrm{pg} \mathrm{dm}^{-3}$ of cobalt ensures the proper course of growth processes. The appropriate cobalt level in insects inhibits caspase production, due to which the intestinal epithelium is not damaged (Cheruiyot et al., 2013).

Both a deficiency and excess of cobalt can result in the appearance of disease symptoms. Sheep are particularly sensitive to cobalt deficiency, as reported by Bishehsari et al. (2010). An excessively low cobalt dose in the feed of these animals becomes the cause of anemia, reduced plasma homocysteine concentration (Stangl et al., 2000; Taugbol et al., 2010) and decreased weight gain leading to anorexia. Symptoms of reduced body mass and shape in goats resulting from cobalt deficiency are confirmed by Kadim et al. (2006). A higher resistance of goats than sheep to low amounts of cobalt present in their body was also found in their study. Another symptom was discolorations appearing on the wool produced by these animals and a characteristic discharge from the ears and eyes. Reduced absorption of nutrients and necessary trace metals, such as copper, iron or nickel, also leads to a decreased quality of meat from these animals (Stangl et al., 2000). According to Taugbol et al. (2010) an excessively high amount of cobalt present in the blood of dairy cows can lead to a reduced level of fatty acid desaturation products in milk and in blood. Excess cobalt can also cause a reduced flow of divalent metals, such as iron and zinc, to udders and disrupt enzymatic activity in the mammary gland cells. Negative effects of cobalt accumulation have also been observed in the organisms of forest animals, e.g on growth processes in wild boar. Yarsan et al. (2014) found that excessively high doses lead to circulatory and nervous system disorders and bone diseases. According to Ceacero et al. 
(2009) deer are among the forest mammals which are best able to regulate cobalt absorption.

Other symptoms of the effect of cobalt include lower animal weight gain and a higher mortality of the born progeny. The surviving progeny can inherit the same defects as parental organisms. Due to the carcinogenic effect of cobalt compounds, it can also lead to the inhibition of DNA repair processes, change gene expression patterns or generate oxygen and nitrogen in a reactive form. It can significantly affect the FAS signal and the caspase pathways similar to this signal, thus contributing to the induction of apoptosis (Wang et al., 2007; Cheruiyot et al., 2013).

The presence of different kinds of cobalt compounds in the air and food can significantly contribute to their excessive accumulation in bird organs. Albayrak and Mor (2011) report that these compounds accumulate in similar amounts in the organs of both sparrow sexes. The only exception is female kidneys, where much higher cobalt contents were found than in male kidneys. These differences are the result of the metabolism of cobalt participating in the activity of sex hormones. Females can contain much higher cobalt contents than males due to an increased amount of feed consumed during egg formation. After eggs are laid, cobalt content in female organisms decreases (Norouzi et al., 2012). A study by Mansouri et al. (2012) on cobalt content in the organs of seabirds shows the opposite tendency, which is affected by moulting. It was also found that cobalt content in the organs of migratory birds was higher than in the organs of sedentary birds, which is significantly affected by the quality of the consumed feed.

Increased cobalt contents can also accumulate in bird feathers as a result of interstitial excretion from their internal organs (Norouzi et al., 2012). Determining the cobalt content in young feathers allows its concentration in blood to be determined, while in older feathers it is not possible due to blood flow changes (Malik and Zeb, 2009). Another animal organism sensitive to cobalt contamination are the larvae of the silkworm Antheraea assama (Devi et al., 2014). Excessive cobalt concentration in its body prevents it reaching the stage at which it is able to produce silk and may cause death.

\section{Effect of cobalt on the human body}

Cobalt in the human body, as in animals, performs an important role in the formation of vitamin $B_{12}$ (Dobrowolski and Otto, 2012). According to ATSDR (2004) $0.1 \mu \mathrm{mol}$ of cobalt in the form of vitamin $\mathrm{B}_{12}$ supplies a necessary amount of cobalt to the human body. The highest cobalt intake which does not cause negative effects is $1800 \mu \mathrm{mol}$. Vitamin $\mathrm{B}_{12}$ deficiency is supplemented, apart from its supply in plant and animal products to the human body, also by the application of drugs (Ulusoy et al., 2012). Its deficiency in the human body leads to the appearance of anemia, resulting from a low amount of produced vitamin $\mathrm{B}_{12}$. Another manifestation of a cobalt deficiency in the human body is disturbed functioning of the alimentary, nervous and osseous systems (Jonnalagadda et al., 2008; Soylak et al., 2012).

The disease symptoms resulting from exceeding the permissible dose include, among others, allergic reactions, lung and heart diseases (Basu et al., 2010; Díaz-Rizo et al., 2012; Dobrowolski and Otto, 2012; Ryuko et al., 2012; Ulusoy et al., 2012; Devi et al., 2014). Intensification of the above symptoms is most often encountered in industrial plants, where exposure to the harmful effect of this element is much higher than in other places with a human presence (Benderli-Cihan et al., 2011; Pietrodangelo et al., 2014). 
Basu et al. (2010) and Ryuko et al. (2012) report that the most frequent symptoms of potassium excess are skin inflammations and asthma. Frequent use of tools which contain cobalt admixtures, as well as the presence in industrial plants, significantly affects the induction of allergic reactions, mainly on the skin of the hands. The occupations particularly exposed to such risks are carpenters and metal workers (Thyssen et al., 2011).

The harmful effect of cobalt can also be the result of absorbing its too high dose with food and drinking water (Obiri, 2007; Upadhyaya et al., 2014). This is particularly important for pregnant women who, depending on the type of consumed food, can accumulate substantial amounts of cobalt in their bodies, which also affects the developing fetus. This was confirmed by Chan-Hon-Tong et al. (2013) who found that a group of tested pregnant women eating mainly fish had a higher blood cobalt content than the women consuming sweets, fruit, milk products and soups. A study by Foster et al. (2012) did not find, however, differences in the blood cobalt content of pregnant women depending on consumed food. Due to genotoxic properties, it is important that the cobalt limit is not exceeded (Chan-Hon-Tong et al., 2013). A low cobalt content present in alcoholic beverages can cause the appearance of disease symptoms. This was confirmed in a study by Ulusoy et al. (2012) where it was found that the consumption of beer with a content of cobalt chloride from 1 to $2 \mathrm{mgdm}^{-3}$ caused changes in the nails of palms and feet, called dyshidrosis. Other symptoms include frequent vomiting and diarrhea, blood pressure changes or headaches. High cobalt contents also lead to damage to the immunological system (Bezerra et al., 2014; Valera et al., 2014). Another symptom of exceeding the permissible dose is damage to DNA and disruption of its repair. Cobalt toxicity has a stronger effect in the presence of iron, to which it is linked by similar atomic properties (Ryuko et al., 2012).

Due to its quite high solubility in systemic fluids, it becomes more mobile and also more harmful to all internal organs. Benderli-Cihan et al. (2011) found much higher cobalt contents in the hair of women with breast cancer than in healthy women, as well as the possibility of cobalt accumulation in nails and teeth. The defense reaction of the body to the presence of an excessively high cobalt dose involves physiological processes. Therefore, its amounts are highest in kidneys and liver (Ulusoy et al., 2012). Cobalt harmfulness in the human body is also associated with the radiation of isotopes of this element, which are the cause of many short- and long-term diseases. An excessively high cobalt isotope accumulation also leads to an increased cancer risk (Bezerra et al., 2014).

\section{Summary}

Apart from natural cobalt contents in the environment, pollution with this element has begun to increase in recent years. The main cause of this is the growing extraction and manifold application of cobalt in different branches of industry (Biswas et al., 2013). The appearance of cobalt levels exceeding the environmental threshold levels has led, however, to disturbances in the proper functioning of living organisms. Not only animals or plants which are the first component of the food chain are at risk, but also the subsequent trophic levels, where accumulated cobalt contents show signs of toxicity (Maguire and Collins, 2001; Basu et al., 2010). The application of sorbents to soil (especially organic matter and calcium oxide) reduce the effect of cobalt on soil organisms and plants. A very important role in the removal of cobalt from soil plays 
phytoremediation by plant hyperaccumulators. High cobalt doses are not, however, the only cause of its negative influence on living organisms. The presented literature review shows that cobalt is also an indispensable dietary micronutrient for living organisms, from microorganisms to the human body. Cobalt deficiencies cause many diseases, whose treatment is a long-lasting process requiring, in most cases, diet adjustment to the dietary needs of a given organism (Soylak et al., 2013).

Focusing on the elements included in the group of heavy metals is useful in assessing environmental pollution. However, it would also be advisable to systematically monitor cobalt content in the environment (especially the soil environment), which affects the quality of produced feed and food, which consequently directly affects the absorption of optimal cobalt amounts by living organisms.

Acknowledgements. This study was supported by the Ministry of Science and Higher Education funds for statutory activity.

\section{REFERENCES}

[1] Abd-Alla, M. H., Bagy, M. K., Wahab, A., Bashandy, S. R. (2014): Activation of Rhizobium tibeticum with flavonoids anhances nodulation, nitrogen fixation and growth of fenugreek (Trigonella foenum-graecum L.) grown in cobalt polluted soil. - Archives of Environmental Contamination \& Toxicology 66(2): 303-315. https://doi.org/10.1007/s00244-013-9980-7.

[2] Abdallah, M. A. (2013): Bioaccumulation of heavy metals in mollusca species and assessment of potential risks to human health. - Bulletin of Environmental Contamination \& Toxicology 90(5): 552-557. https://doi.org/10.1007/s00128-013-0959-x.

[3] Abdel-Razek, A. S., Abdel Ghany, T. M., Mahmoud, S. A., El Sheikh, H. H., Mahmoud, M. S. (2009): The use of free and immobilized Cunninghamella elegans for removing cobalt ions from aqueous waste solutions. - World Journal of Microbiology \& Biotechnology 25(12): 2137-2145. https://doi.org/10.1007/s11274-009-0118-z.

[4] Abskharon, R. N. N., Hassan, S. H. A., Kabir, M. H., Qadir, S. A., Gad El Rab, S. M. F., Wang, M. H. (2010): The role of antioxidants enzymes of E. coli ASU3, a tolerant strain to heavy metals toxicity, in combating oxidative stress of copper. - World Journal of Microbiology \& Biotechnology 26(2): 241-247. https://doi.org/10.1007/s11274-0090166-4.

[5] Agbenin, J. O. (2002): The impact of long-term cultivation and management history on the status and dynamics of cobalt in a savanna Alfisol in Nigeria. - European Journal of Soil Science 53(2): 169-174. https://doi.org/10.1046/j.1365-2389.2002.00433.x.

[6] Agbenin, J. O., Danko, M., Welp, G. (2009): Soil and vegetable compositional relationships of eight potentially toxic metals in urban garden fields from northern Nigeria. - Journal of the Science of Food \& Agriculture 89(1): 49-54. https://doi.org/10.1002/jsfa.3409.

[7] Akbar, F. M., Zafar, M., Hamid, A., Ahmed, M., Khaliq, A., Khan, M. R., Rehman, Z. (2013): Interactive effect of cobalt and nitrogen on growth, nodulation, yield and protein content of field grown pea. - Horticulture Environment \& Biotechnology 54(6): 465-474. https://doi.org/10.1007/s13580-013-0001-6.

[8] Albayrak, T., Mor, F. (2011): Comparative tissue distribution of heavy metals in House Sparrow (Passer domesticus, Aves) in polluted and reference sites in Turkey. - Bulletin of Environmental Contamination \& Toxicology 87(4): 457-462. https://doi.org/10.1007/s00128-011-0364-2. 
[9] Alquezar, R., Anastasi, A. (2013): The use of the cyanobacteria, Cyanobium sp., as a suitable organism for toxicity testing by flow cytometry. - Bulletin of Environmental Contamination \& Toxicology 90(6): 684-690. https://doi.org/10.1007/s00128-013-09778.

[10] Al-Shiwafi, N., Rushdi, A. I., Ba-Issa, A. (2005): Trace metals in surface seawaters and sediments from various habitats of the Red Sea coast of Yemen. - Environmental Geology 48(4-5): 590-598. https://doi.org/10.1007/s00254-005-1315-1.

[11] Amir, H., Pineau, R. (2003): Release of Ni and Co by microbial activity in New Caledonian ultramafic soils. - Canadian Journal of Microbiology 49(4): 288-293. https://doi.org/10.1139/W03-039.

[12] Antony, R., Sujith, P. P., Fernandes, S. O., Verma, P., Khedekar, V. D., Loka Bharathi, P. A. (2011): Cobalt immobilization by manganese oxidizing bacteria from the Indian Ridge System. - Current Microbiology 62(3): 840-849. https://doi.org/10.1007/s00284-0109784-1.

[13] Ashfaq, M., Ali, S., Hanif, M. A. (2009): Bioaccumulation of cobalt in silkworm (Bombyx mori L.) in relation to mulberry, soil and wastewater metal concentrations. Process Biochemistry 44(10): 1179-1184. https://doi.org/ 10.1016/j.procbio.2009.05.006.

[14] Ashraf, W., Mian, A. A. (2008): Levels of selected heavy metals in black tea varieties consumed in Saudi Arabia. - Bulletin of Environmental Contamination \& Toxicology 81(1): 101-104. https://doi.org/10.1007/s00128-008-9402-0.

[15] ATSDR (2004): Toxicological profile for cobalt. - gency for Toxic Substances and Disease Registry. U.S. Department of Health and Human Services, Public Health Service, Atlanta, GA.

[16] Balestrazzi, A., Bonadei, M., Quattrini, E., Carbonera, D. (2009): Occurrence of multiple metal-resistance in bacterial isolates associated with transgenic white poplars (Populus alba L.). - Annals of Microbiology 59(1): 17-23. https://doi.org/10.1007/BF03175593.

[17] Banks, C. J., Zang, Y., Jiang, Y., Heaven, S. (2012): Trace element requirements for stable food waste digestion at elevated ammonia concentration. - Bioresource Technology 104: 127-135. https://doi.org/10.1016/j.biortech.2011.10.068.

[18] Basu, N., Abare, M., Buchanan, S., Cryderman, D., Nam, D. H., Sirkin, S., Schmitt, S., $\mathrm{Hu}, \mathrm{H}$. (2010): A combined ecological and epidemiologic investigation of metal exposures amongst Indigenous peoples near the Marlin Mine in Western Guatemala. $\begin{array}{llll}\text { Science of the Total Environment } & \text { 409(1): }\end{array}$ https://doi.org/10.1016/j.scitotenv.2010.09.041.

[19] Batista, D., Muricy, G., Rocha, R. C., Miekeley, N. F. (2014): Marine sponges with contrasting life histories can be complementary biomonitors of heavy metal pollution in coastal ecosystems. - Environmental Science \& Pollution Research 21(9): 5785-5794. https://doi.org/10.1007/s11356-014-2530-7.

[20] Bem, H., Gallorini, M., Rizzio, E., Krzemińska, M. (2003): Comparative studies on the concentrations of some elements in the urban air particulate matter in Łodź City of Poland and in Milan, Italy. - Environment International 29(4): 423-428. https://doi.org/ 10.1016/S0160-4120(02)00190-3.

[21] Benderli-Cihan, Y., Sözen, S., Oztürk-Yildirim, S. (2011): Trace elements and heavy metals in hair of stage III breast cancer patients. - Biological Trace Element Research 144(1-3): 360-379. https://doi.org/10.1007/s12011-011-9104-z.

[22] Ben-Fredj, F., Wali, A., Khadhraoui, M., Han, J., Funamizu, N., Ksibi, M., Isoda, H. (2014): Risk assessment of heavy metal toxicity of soil irrigated with treated wastewater using heat shock proteins stress responses: case of El Hajeb, Sfax, Tunisia. Environmental Science \& Pollution Research 21(6): 4716-4726. https://doi.org/10.1007/s11356-013-2411-5.

[23] Benlloch-González, M., Romera, J., Cristescu, S., Harren, F., Fournier, J. M., Benlloch, M. (2010): $\mathrm{K}^{+}$starvation inhibits water-stress-induced stomatal closure via ethylene synthesis in sunflower plants. - Journal of Experimental Botany 61(4): 1139-1145. https://doi.org/10.1093/jxb/erp379. 
[24] Bezerra, J. D., Santos-Amaral, R., Santos-Júnior, J. A., Genezini, F. A., Menezes, R. S., De Oliviera, I. A. (2014): Characterization of heavy metals in a uranium ore region of the state of Pernambuco, Brazil. - Bulletin of Environmental Contamination \& Toxicology 92(3): 270-273. https://doi.org/10.1007/s00128-013-1183-4.

[25] Biesalski, H. K., Grimm, P. (2012): Żywienie. Atlas i podręcznik. Wyd. I. - Elsevier, Amsterdam.

[26] Bishehsari, S., Mehdi-Tabatabaei, M., Aliarabi, H., Alipour, D., Zamani, P., Ahmadi, A. (2010): Effect of dietary cobalt supplementation on plasma and rumen metabolites in Mehraban lambs. - Small Ruminant Research 90(1-3): 170-173. https://doi.org/10.1016/j.smallrumres.2010.02.010.

[27] Biswas, S., Dey, R., Mukherjee, S., Banerjee, P. C. (2013): Bioleaching of nickel and cobalt from lateritic chromite overburden using the culture filtrate of Aspergillus niger. Applied Biochemistry \& Biotechnology 170(7): 1547-1559. https://doi.org/10.1007/s12010-013-0289-9.

[28] Briand, M. J., Letourneur, Y., Bonnet, X., Wafo, E., Fauvel, T., Brischoux, F., Guillou, G., Bustamante, P. (2014): Spatial variability of metallic and organic contamination of anguilliform fish in New Caledonia. - Environmental Science \& Pollution Research 21(6): 4576-4591. https://doi.org/10.1007/s11356-013-2327-0

[29] Canepari, S., Astolfi, M. L., Farao, C., Maretto, M., Frasca, D., Marcoccia, M., Perrino, C. (2014): Seasonal variations in the chemical composition of particulate matter: a case study in the Po Valley. Part II: concentration and solubility of micro- and trace-elements. - Environmental Science \& Pollution Research 21(6): 4010-4022. https://doi.org/10.1007/s11356-013-2298-1.

[30] Cavet, J. S., Borrelly, G. P., Robinson, N. J. (2003): Zn, Cu and Co in cyanobacteria: selective control of metal availability. - FEMS Microbiology Reviews 27(2-3): 165-181.

[31] Ceacero, F., Landete-Castillejos, T., García, A. J., Estévez, J. A., Martinez, A., Calatayud, A., Gaspar-López, E., Gallego, L. (2009): Free-choice mineral consumption in Iberian red deer (Cervus elaphus hispanicus) response to diet deficiencies. - Livestock Science 122(2-3): 345-348. https://doi.org/10.1016/j.livsci.2008.08.002.

[32] Chan-Hon-Tong, A., Charles, M. A., Forhan, A., Heude, B., Sirot, V. (2013): Exposure to food contaminants during pregnancy. - Science of the Total Environment 458-460: 2735. https://doi.org/10.1016/j.scitotenv.2013.03.100.

[33] Chanpiwat, P., Sthiannopkao, S. (2014): Status of metal levels and their potential sources of contamination in Southeast Asian rivers. - Environmental Science \& Pollution Research 21(1): 220-233. https://doi.org/10.1007/s11356-013-1858-8.

[34] Chatterjee, C., Dube, B. K. (2005): Impact of pollutant elements on vegetables growing in sewage-sludge-treated soils. - Journal of Plant Nutrition 28(10): 1811-1820. https://doi.org/10.1080/01904160500251175.

[35] Chatterjee, C., Gopal, R., Dube, B. K. (2006): Physiological and biochemical responses of French bean to excess cobalt. - Journal of Plant Nutrition 29(1): 127-136. https://doi.org/10.1080/01904160500416513.

[36] Chatterjee, J., Chatterjee, C. (2002): Amelioration of phytotoxicity of cobalt by high phosphorus and its withdrawal in tomato. - Journal of Plant Nutrition 25(12): 2731-2743. https://doi.org/10.1081/PLN-120015535.

[37] Chatterjee, J., Chatterjee, C. (2003): Management of phytotoxicity of cobalt in tomato by chemical measures. - Plant Science 164(5): 793-801. https://doi.org/10.1016/S01689452(03)00066-9.

[38] Chaudhari, B. H., Parmar, J. K., Mali, R. H., Bumbadiya, N. H. (2017): Effect of Co level and FYM on growth and yield of fodder maize. - International Journal of Chemical Studies 5(1): 327-329.

[39] Cheruiyot, D. J., Boyd, R. S., Moar, W. J. (2013): Exploring lower limits of plant elemental defense by cobalt, copper, nickel, and zinc. - Journal of Chemical Ecology 39(5): 666-674. https://doi.org/10.1007/s10886-013-0279-y. 
[40] Chmielowska-Bąk, J., Lefèvre, I., Lutts, S., Kulik, A., Deckert, J. (2014): Effect of cobalt chloride on soybean seedlings subjected to cadmium stress. - Acta Societatis Botanicorum Poloniae 83(3): 201-207. https://doi.org/10.5586/asbp.2014.027.

[41] Ciećko, Z., Kalembasa, S., Wyszkowski, M., Rolka, E. (2005): The magnesium content in plants on soil contaminated with cadmium. - Polish Journal of Environmental Studies 14(3): 365-370.

[42] Collins, R. N., Kinsela, A. S. (2011): Pedogenic factors and measurements of the plant uptake of cobalt. - Plant \& Soil 339(1): 499-512. https://doi.org/10.1007/s11104-0100584-y.

[43] Dávila-Rangel, J. I., Solache-Ríos, M. (2006): Sorption of cobalt by two Mexican clinoptilolite rich tuffs zeolitic rocks and kaolinite. - Journal of Radioanalytical \& Nuclear Chemistry 270(2): 465-471.

[44] Defarge, N., Spiroux de Vendômois, J., Séralinia, G. E. (2018): Toxicity of formulants and heavy metals in glyphosate-based herbicides and other pesticides. - Toxicology Reports 5: 156-163. https://doi.org/10.1016/j.toxrep.2017.12.025.

[45] de Jesus, I. S., da Silva-Medeiros, R. L., Cestari, M. M., de Almeida-Bezerra, M., de Mello-Affonso, P. R. (2014): Analysis of metal contamination and bioindicator potential of predatory fish species along Contas River basin in northeastern Brazil. - Bulletin of Environmental Contamination \& Toxicology 92(5): 551-556. https://doi.org/10.1007/s00128-013-1188-z.

[46] Devi, G., Gopal-Bhattacharyya, K., Mahanta, L. B., Devi, A. (2014): Trace metal composition of PM2.5, soil, and Machilus bombycina leaves and the effects on Antheraea assama silk worm rearing in the oil field area of northeastern India. - Water Air \& Soil Pollution 225: 1884-1897. https://doi.org/10.1007/s11270-014-1884-2.

[47] Dhaneesh, K. V., Gopi, M., Noushad, K. M., Ganeshamurthy, R., Kumar, T. T., Balasubramanian, T. (2012): Determination of metal levels in thirteen fish species from Lakshadweep Sea. - Bulletin of Environmental Contamination \& Toxicology 88(1): 6973. https://doi.org/10.1007/s00128-011-0459-9.

[48] Díaz-Rizo, O., Hernández-Merlo, M., Echeverría-Castillo, F., Arado-López, J. O. (2012): Assessment of metal pollution in soils from a former Havana (Cuba) solid waste open dump. - Bulletin of Environmental Contamination \& Toxicology 88(2): 182-186. https://doi.org/10.1007/s00128-011-0505-7.

[49] Directive 2010/75/EU of the European Parliament and of the Council of 24 November (2010): On industrial emissions (integrated pollution prevention and control). - Official Journal of the European Union L 334/17-119.

[50] Dobrowolski, R., Otto, M. (2012): Determination of nickel and cobalt in reference plant materials by carbon slurry sampling GFAAS technique after their simultaneous preconcentration onto modified activated carbon. - Journal of Food Composition \& Analysis 26(1-2): 58-65. https://doi.org/10.1016/j.jfca.2012.03.002.

[51] Dong Cho, Y., Kim, J., Chung Kim, D. (2012): Cobalt-requiring 5'-deoxy-5'methylthioadenosine nucleosidase from soybean (Glycine max) cotyledon. - Journal of Plant Biochemistry \& Biotechnology 21(1): 113-116. https://doi.org/10.1007/s13562-110061-6.

[52] Dos Anjos-Paulino, S., Oliveira, R. L., Loyola, J., Minho, A. S., Arbilla, G., Quiterio, S. L., Escaleira, V. (2014): Trace metals in PM10 and PM 2,5 samples collected in a highly industrialized chemical/petrochemical area and its urbanized surroundings. - Bulletin of Environmental Contamination \& Toxicology 92(5): 590-595. https://doi.org/10.1007/s00128-014-1219-4.

[53] Ebrahimi, M., Panahi, R., Dabbagh, R. (2009): Evaluation of native and chemically modified Sargassum glaucescens for continous biosorption of Co(II). - Applied Biochemistry \& Biotechnology 158(3): 736-746. https://doi.org/10.1007M2010-0088389-7. 
[54] Edwards, A. C., Coull, M., Sinclair, A. H., Walker, R. L., Watsun, C. A. (2012): Elemental status $(\mathrm{Cu}, \mathrm{Mo}, \mathrm{Co}, \mathrm{B}, \mathrm{S}$ and $\mathrm{Zn})$ of Scottish agricultural soils compared with a soil-based risk assessment. - Soil Use \& Management 28(2): 167-176. https://doi.org/10.1111/j.1475-2743.2012.00408.x.

[55] Elleuche, S., Fodor, K., von der Heyde, A., Klippel, B., Wilmanns, M., Antranikian, G. (2014): Group III alcohol dehydrogenase from Pectobacterium atrosepticum: insights into enzymatic activity and organization of the metal ion-containing region. - Applied Microbiology \& Biotechnology 98(9): 4041-4051. https://doi.org/10.1007/s00253-0135374-z.

[56] Elliot, D., Litzinger, T. (2015): 2014 Production Statistics. - Cobalt News 15/2: 1-8.

[57] Esther, J., Panda, S., Behera, S. K., Sukula, L. B., Pradhan, N., Mishra, B. K. (2013): Effect of dissimilatory $\mathrm{Fe}(\mathrm{IIII})$ reducers on bio-reduction and nickel-cobalt recovery from Sukinda chromite-overburden. - Bioresource Technology 146: 762-766. https://doi.org/10.1016/j.biortech.2013.07.103.

[58] Faucon, M. P., Ngoy-Shutcha, M., Meerts, P. (2007): Revisiting copper and cobalt concentrations in supposed hyperaccumulators from SC Africa: influence of washing and metal concentrations in soil. - Plant \& Soil 301: 29-36. https://doi.org/10.1007/s11104007-9405-3.

[59] Faucon, M. P., Colinet, G., Mhay, G., Ngongo-Luhembwe, M., Verburggen, N., Meerts, P. (2009): Soil influence on $\mathrm{Cu}$ and Co uptake and plant size in the cuprophytes Crepidorhopalon perennis and C. tenuis (Scrophulariaceae) in SC Africa. - Plant \& Soil 317: 201-212. https://doi.org/10.1007/s11104-008-9801-3.

[60] Fermoso, F. G., Bartecek, J., Lens, P. N. (2010): Effect of vitamin B12 pulse addition on the performance of cobalt deprived anaerobic granular sludge bioreactors. - Bioresource Technology 101(14): 5201-5205. https://doi.org/10.1016/j.biortech.2010.02.047.

[61] Foster, W. G., Cheung, A. P., Davis, K., Graves, G., Jarrell, J., Leblanc, A., Liang, C. L., Leech, T., Walker, M., Weber, J. P., Von Oostdam, J. (2012): Circulating metals and persistent organic pollutant concentrations in Canadian and non-Canadian born primiparous women from five Canadian centres: results of a pilot biomonitoring study. Science of the Total Environment 435-436: 326-336 https://doi.org/10.1016/j.scitotenv.2012.06.070.

[62] Freeman, J. L., Persans, M. W., Nieman, K., Salt, D. E. (2005): Nickel and cobalt resistance engineered in Escherichia coli by overexpression of serine acetyltransferase from the nickel hyperaccumulator plant Thlaspi goesingense. - Applied \& Environmental Microbiology 71(12): 8627-8633. https://doi.org/10.1128/AEM.71.12.8627-8633.2005.

[63] Fujikawa, Y., Fukui, M. (2001): Vertical distribution of trace metals in natural soil horizons from Japan. Part 2. Effects of organic components in soil. - Water, Air \& Soil Pollution 131(1-4): 305-328. https://doi.org/10.1023/A:1011927802703.

[64] Ghandour, I. M., Basaham, S., Al-Washmi, A., Masuda, H. (2014): Natural and anthropogenic controls on sediment composition of an arid coastal environment: Sharm Obhur, Red Sea, Saudi Arabia. - Environmental Monitoring \& Assessment 186(3): 14651484. https://doi.org/10.1007/s10661-013-3467-x.

[65] Ghassabzadeh, H., Torab-Mostaedi, M., Mohaddespour, A., Ghannadi, M. M., Ahmadi, S. J., Zaheri, P. (2010): Characterizations of $\mathrm{Co}$ (II) and $\mathrm{Pb}$ (II) removal process from aqueous solutions using expanded per-lite. - Desalination 261(1-2): 73-79. https://doi.org/10.1016/j.desal.2010.05.028.

[66] Gopal, R., Dube, B. K., Sinha, P., Chatterjee, C. (2003): Cobalt toxicity effects on growth and metabolism of tomato. - Communications in Soil Science \& Plant Analysis 34(5-6): 619-628. https://doi.org/10.1081/CSS-120018963.

[67] Guo, Y. J., Di, H. J., Cameron, K. C., Li, B. (2014): Effect of application rate of a nitrification inhibitor, dicyandiamide (DCD), on nitrification rate, and ammoniaoxidizing bacteria and archaea growth in a grazed pasture soil: an incubation study. - 
Journal of Soils \& Sediments 14(5): 897-903. https://doi.org/10.1007/s11368-013-08437.

[68] Guzmán-Morales, J., Morton-Bermea, O., Hernández-Álvarez, E., Rodríguez-Salazar, M. T., García-Arreola, M. E., Tapia-Cruz, V. (2011): Assessment of atmospheric metal pollution in the urban area of Mexico City, using Ficus benjamina as biomonitor. Bulletin of Environmental Contamination \& Toxicology 86(5): 495-500. https://doi.org/10.1007/s00128-011-0252-9.

[69] Hau, H. H., Gibert, A., Coursolle, D., Gralnick, J. A. (2008): Mechanism and Consequences of anaerobic respiration of cobalt by Shewanella oneidensis strain MR-1. Applied \& Environmental Microbiology 74(22): 6880-6886. https://doi.org/10.1128/AEM.00840-08.

[70] Heimbürger, L. E., Migon, C., Dufour, A., Chiffoleau, J. F., Cossa, D. (2010): Trace metal concentrations in the North-western Mediterranean atmospheric aerosol between 1986 and 2008: Seasonal patterns and decadal trends. - Science of the Total Environment 408(13): 2629-2638. https://doi.org/10.1016/j.scitotenv.2010.02.042.

[71] Hierro, A., Olías, M., Ketterer, M. E., Vaca, F., Borrego, J., Cánovas, C. R., Bolivar, J. P. (2014): Geochemical behavior of metals and metalloids in an estuary affected by acid mine drainage (AMD). - Environmental Science \& Pollution Research 21(4): 2611-2627. https://doi.org/10.1007/s11356-013-2189-5.

[72] Hlima, H. B., Aghajari, N., Ali, M. B., Haser, R., Bejar, S. (2012): Engineered glucose isomerase from Streptomyces sp. SK is resistant to $\mathrm{Ca}^{2+}$ inhibition and $\mathrm{Co}^{2+}$ independent. - Journal of Industrial Microbiology \& Biotechnology 39(4): 537-546. https://doi.org/10.1007/s10295-011-1061-1.

[73] Hoffman, D. R., Anderson, P. P., Schubert, C. M., Gault, M. B., Blanford, W. J., Sandrin, T. R. (2010): Carboxymethyl-beta-cyclodextrin mitigates toxicity of cadmium, cobalt, and copper during naphthalene biodegradation. - Bioresource Technology 101(8): 26722677. https://doi.org/10.1016/j.biortech.2009.10.073.

[74] Holland, A., Duivenvoorden, L. J., Kinnear, S. H. W. (2013): Humic substances increase survival of freshwater shrimp Caridina sp. D to acid mine drainage. - Archives of Environmental Contamination \& Toxicology 64(2): 263-272. https://doi.org/10.1007/s00244-012-9823-y.

[75] Hong, Q., Dong-Li, L., Yu-You, L. (2012): High-solid mesophilic methane fermentation of food waste with an emphasis on iron, cobalt, and nickel requirements. - Bioresource Technology 103(1): 20-27. https://doi.org/10.1016/j.biortech.2011.09.036.

[76] Hu, D., Cheng, M., Hu, K., Zhang, W., Yang, Y., Xu, Q. (2019): Evaluation of cobalt hyperaccumulation and tolerance potential of the duckweed (Lemna minor L.). $\begin{array}{llllll}\text { Ecotoxicology } \quad \& \quad \text { Environmental } & \text { Safety } & \text { 179: } & \text { 79-87. }\end{array}$ https://doi.org/10.1016/j.ecoenv.2019.04.058.

[77] Hu, X., Wang, C., Wang, L., Zhang, R., Chen, H. (2014): Influence of temperature, pH and metal ions on guaiacol oxidation of purifield laccase from Leptographium qinlingensis. - World Journal of Microbiology \& Biotechnology 30(4): 1285-1290. https://doi.org/10.1007/s11274-013-1554-3.

[78] Huang, L., Li, T., Liu, C., Quan, X., Chen, L., Wang, A., Chen, G. (2013): Synergetic interactions improve cobalt leaching from lithium cobalt oxide in microbial fuel cells. Bioresource Technology 128: 539-546. https://doi.org/10.1016/j.biotech.2012.11.011.

[79] Iqbal, J., Tirmizi, S. A., Shah, M. H. (2012): Non-carcinogenic health risk assessment and source apportionment of selected metals in source freshwater Khanpur Lake, Pakistan. Bulletin of Environmental Contamination \& Toxicology 88: 177-181. https://doi.org/10.1007/s00128-011-0480-z.

[80] Jadoon, S., Malik, A. (2018): A Review of formation, toxicity of reactive oxygen species by heavy metals and tolerance in plants. - International Journal of Biochemistry Research \& Review 21(2): 1-12. https://doi.org/10.9734/IJBCRR/2018/38670. 
[81] Jain, V., Nainawatee, H. S. (2000): Cobalt reduces nitrate inhibition of nodulation in mungbean (Vigna radiata). - Biology \& Fertility of Soils 31(6): 522-524. https://doi.org/10.1007/s003740000203.

[82] Jayasiri, H. B., Vennila, A., Purushothaman, C. S. (2014): Spatial and temporal variability of metals in inter-tidal beach sediment of Mumbai, India. - Environmental Monitoring \& Assessment 186(2): 1101-1111. https://doi.org/10.1007/s10661-013-34417.

[83] Jonnalagadda, S. B., Kindeness, A., Kubayi, S., Cele, M. N. (2008): Macro, minor and toxic elemental uptake and distribution in Hypoxis hemerocallidea, "the African Potato"an edible medicinal plant. - Journal of Environmental Science \& Health, B 43(3): 271280. https://doi.org/10.1080/03601230701771461.

[84] Kabata-Pendias, A., Pendias, H. (2001): Trace Elements in Soils and Plants. Third Ed. CRC Press, Boca Raton, FL.

[85] Kadim, I. T., Mahgoub, O., Al-Ajmi, D., Al-Habsi, K. R., Johnson, E. H. (2006): Comparative effects of low levels of dietary cobalt and parenteral injections of vitamin $\mathrm{B}_{12}$ on body dimensions in different breeds of Omani goats. - Small Ruminant Research 66(1-3): 244-252. https://doi.org/10.1016/j.smallrumres.2005.09.018.

[86] Kang, J., Choi, M. S., Lee, C. B. (2009): Atmospheric metal and phosphorus concentrations, inputs, and their biogeochemical significances in the Japan/East Sea. Science of the Total Environment 407(7): 2270-2284. https://doi.org/10.1016/j.scitotenv.2008.11.047.

[87] Karuppanapandian, T., Kim, W. (2013): Cobalt-induced oxidative stress causes growth inhibition associated with enhanced lipid peroxidation and activates antioxidant responses in Indian mustard (Brassica juncea L.) leaves. - Acta Physiologiae Plantarum 35(8): 2429-2443. https://doi.org/10.1007/s11738-0131277-y.

[88] Keeling, S. M., Stewart, R. B., Anderson, C. W. N., Robinson, B. H. (2003): Nickel and cobalt phytoextraction by the hyperaccumulator Berkheya coddii: implications for polymetallic phytomining and phytoremediation. - International Journal of Phytoremediation 5(3): 235-244. https://doi.org/10.1080/16226510390255689.

[89] Klavins, M., Potapovics, O., Rodinov, V. (2009): Heavy metals in fish from lakes in Lativia: concentrations and trends of changes. - Bulletin of Environmental Contamination \& Toxicology 82(1): 96-100. https://doi.org/10.1007/s00128-008-9510-x.

[90] Koch, D., Nies, D. H., Grass, G. (2007): The RenRA (YohLM) system of Escherichia coli: a contection between nickel, cobalt and iron homeostasis. - Biometals 20(5): 759771. https://doi.org/10.1007/s10534-006-9039-6.

[91] Koigoora, S., Ahmad, I., Pallela, R., Janapala, V. R. (2013): Spatial variation of potentially toxic elements in different grain size fractions of marine sediments from Gulf of Mannar, India. - Environmental Monitoring \& Assessment 185(9): 7581-7589. https://doi.org/10.1007M0661-013-3120-8.

[92] Kosiorek, M., Wyszkowski, M. (2019a): Content of macronutrients in oat (Avena sativa L.) after remediation of soil polluted with cobalt. - Environmental Monitoring \& Assessment 191(389): 1-15. https://doi.org/10.1007/s10661-019-7529-6.

[93] Kosiorek, M., Wyszkowski, M. (2019b): Effect of neutralising substances on reducing influence of cobalt on the content of selected elements in soil. - International Agrophysics 33(2): 153-159. https://doi.org/10.31545/intagr/104618.

[94] Kosiorek, M., Wyszkowski, M. (2019c): Effect of neutralizing substances on the content of trace elements in soil contaminated with cobalt. - Environment Protection Engineering 45(1): 45-55. https://doi.org/10.5277/epe190104.

[95] Kosiorek, M., Wyszkowski, M. (2019d): Remediation of cobalt polluted soil after application of selected substances and using oat (Avena sativa L.). - Environmental Science \& Pollution Research 26: 16762-16780. https://doi.org/10.1007/s11356-01905052-x. 
[96] Kukier, U., Peters, C. A., Chaney, R., Angle, J. S., Roserberg, R. (2004): The effect of pH on metal accumulation in two Alyssum species. - Journal of Environmental Quality 33(6): 2090-2102.

[97] Kun-Tai, L., Dong-Hong, L., Ying-Ping, Z., Yong-Hong, W., Ju, C., Si-Liang, Z. (2008): Influence of $\mathrm{Zn}^{2+}, \mathrm{Co}^{2+}$ and dimethylbenzimidazole on vitamin $\mathrm{B}_{12}$ biosynthesis by Pseudomonas denitrificans. - World Journal of Microbiology \& Biotechnology 24: 25252530. https://doi.org/10.1007/s11274-008-0770-y.

[98] Kuoppamäki, K., Setälä, H., Rantalainen, A. L., Kotze, D. J. (2014): Urban snow indicates pollution originating from road traffic. - Environmental Pollution 195: 56-63. https://doi.org/10.1016/j.envpol.2014.08.019.

[99] Lalah, J. O., Njogu, S. N., Wandiga, S. O. (2009): The effects of $\mathrm{Mn}^{2+}, \mathrm{Ni}^{2+}, \mathrm{Cu}^{2+}, \mathrm{Co}^{2+}$ and $\mathrm{Zn}^{2+}$ ions on pecticide adsorption and mobility in a topical soil. - Bulletin of Environmental Contamination \& Toxicology 83(3): 352-358. https://doi.org/10.1007/s00128-009-9746-0.

[100] Lavoie, M., Fortin, C., Campbell, P. G. C. (2012): Influence of essential elements on cadmium uptake and toxicity in a unicellular green alga: the protective effect of trace zinc and cobalt concentrations. - Environmental Toxicology \& Chemistry 31(7): 1445-1452. https://doi.org/10.1002/ect.1855.

[101] Lefebvre, O., Al-Mamun, A., Ooi, W. K., Tang, Z., Chua, D. H., Ng, H. Y. (2008): An insight into cathode options for microbial fuel cells. - Water Science \& Technology 57(12): 2031-2035 https://doi.org/10.2166/wst.2008.611.

[102] Li, X. L., Chen, C. L., Chang, P. P., Yu, S. M., Wu, W. S., Wang, X. K. (2009): Comparative studies of cobalt sorption and desorption on bentonite, alumina and silica: effect of $\mathrm{pH}$ and fulvic acid. - Desalination 244(1-3): 283-292. https://doi.org/10.1016/j.desal.2008.04.045.

[103] Li, Z., Feng, X., Bi, X., Li, G., Lin, Y., Sun, G. (2014): Probing the distribution and contamination levels of 10 trace metal/metalloids in soil near a $\mathrm{Pb} / \mathrm{Zn}$ smelter in Middle China. - Environmental Science \& Pollution Research 21(6): 4149-4162. https://doi.org/10.1007/s11356-013-2407-1.

[104] Liu, Z. S., Erhan, S. Z. (2002): Conversion of soybean oil into ion exchange resins: Removal of copper (II), nickel (II) and cobalt (II) ions from dilute aqueous solution using cocarboxylate-containing resin. - Journal of Applied Polymer Science 84: 2386-2396. https://doi.org/10.1002/app.10504.

[105] Lock, K., De Schamphelaere, K. A. C., Because, S., Criel, P., Van Eeckhout, H., Janssen, C. R. (2006): Development and validation of an acute biotic ligand model (BLM) predicting cobalt toxicity in soil to the potworm Enchytraeus albidus. - Soil Biology \& Biochemistry 38(7): 1924-1932. https://doi.org/10.1016/j.soilbio.2005.12.014.

[106] Luo, D., Zheng, H., Chen, Y., Wang, G., Fenghua, D. (2010): Transfer characteristics of cobalt from soil to crops in the suburban areas of Fujian Province, Southeast China. Journal of Environmental Management 91(11): 2248-2253. https://doi.org/10.1016/j.jenvman.2010.06.001.

[107] Maguire, J. L., Collins, R. A. (2001): Effects of cobalt hexammine on folding and selfcleavage of the Neurospora VS Ribozyme. - Journal of Molecular Biology 309: 45-56. https://doi.org/10.1006/jmbi.2001.4625.

[108] Mahapatra, P. S., Ray, S., Das, N., Mohanty, A., Ramulu, T. S., Das, T., Chaudhury, G. R., Das, S. N. (2013): Urban air-quality assessment and source apportionment studies for Bhubaneshwar, Odisha. - Theoretical \& Applied Climatology 112(1): 243-251. https://doi.org/10.1007/s00704-012-0732-9.

[109] Malik, R. N., Zeb, N. (2009): Assessment of environmental contamination using feathers of Bubulcus ibis L., as a biomonitor of heavy metal pollution, Pakistan. - Ecotoxicology 18(5): 522-536. https://doi.org/10.1007/s10646-009-0310-9.

[110] Mansouri, B., Pourkhabbaz, A., Babaei, H., Hoshyari, E., Khodaparast, S. H., Mirzajani, A. (2012): Assessment of trace-metal concentrations in Western Reef heron (Egretta 
gularis) and Siberian gull (Larus heuglini) from southern Iran. - Archives of Environmental Contamination \& Toxicology 63(2): 280-287. https://doi.org/10.1007/s00244-012-9762-7.

[111] Marrero, J., Auling, G., Coto, O., Nies, D. H. (2007): High- level resistance to cobalt and nickel but probably no transenvelope efflux: metal resistance in the Cuban Serratia marcescens Strain C-1. - Microbial Ecology 53(1): 123-133. https://doi.org/10.1007/s00248-006-9152-7.

[112] Muthaura, C., Mucheru-Muna, M., Zingore, S., Kihara, J., Muthamia, J. (2017): Effect of application of different nutrients on growth and yield parameters of maize (Zea mays), case of Kandara Murang'a County. - ARPN Journal of Agricultural \& Biological Science 12(1): 19-33.

[113] McLeod, K. W., Ciravolo, T. (2007): Cobalt uptake by Nyssa aquatica, Nyssa sylvatica var. Biflora and Taxodium distichum seedlings. - Wetlands 27(1): 40-43. https://doi.org/10.1672/0277-5212(2007)27[40:CUBNAN]2.0.CO;2.

[114] Minamihata, K., Goto, M., Kamiya, N. (2012): Activation of Pyrococcus furiosus alkaline phosphatase by divalent metal ions. - Biotechnology Letters 34(11): 2055-2060. https://doi.org/10.1007/s10529-012-0998-0.

[115] Miranda, R. M., Tomaz, E. (2008): Characterization of urban aerosol in Campinas, São Paulo, Brazil. - $\quad$ Atmospheric Research 87(2): 147-157. https://doi.org/10.1016/j.atmosres.2007.08.002.

[116] Modrzewska, B., Wyszkowski, M. (2014): Trace metals content in soils along the State Road 51 (northeastern Poland). - Environmental Monitoring \& Assessment 186(4): 25892597. https://doi.org/10.1007/s10661-013-3562-z.

[117] Mohiuddin, K. M., Otomo, K., Ogawa, Y., Shikazono, N. (2012): Seasonal and spatial distribution of trace elements in the water and sediments of the Tsurumi River in Japan. Environmental Monitoring \& Assessment 184(1): 265-279. https://doi.org/10.1007/s10661-011-1966-1.

[118] Mollah, A. S., Begum, A. (2001): A study on transfer factors of Co-60 and Zn-65 from soil to plants in the tropical environment of Bangladesh. - Environmental Monitoring \& Assessment 68(1): 91-97. https://doi.org/10.1023/A:1010791007732.

[119] Mukherjee, S., Kaviraj, A. (2011): Ecotoxicological assessment of cobalt used as supplement in the diet of common carp Cyprinus carpio. - Bulletin of Environmental Contamination \& Toxicology 87(5): 527-530. https://doi.org/10.1007/s00128-011-0384y.

[120] Murtaza, G., Ghafoor, A., Qadir, M. (2008): Accumulation and implications cadmium, cobalt and manganese in soils and vegetables irrigated with city effluent. - Journal of the Science of Food \& Agriculture 88(1): 100-107. https://doi.org/10.1002/jsfa.

[121] Nagpal, N. K. (2004): Water Quality Guidelines for Cobalt. - Ministry of Water, Land and Air Protection, Water Protection Section, Water, Air and Climate Change Branch, Victoria.

[122] Narendrula, R., Nkongolo, K. K., Beckett, P. (2012): Comparative soil metal analyses in Sudbury (Ontario, Canada) and Lubumbashi (Katanga, DR-Kongo). - Bulletin of Environmental Contamination $\quad \& \quad$ Toxicology 88(2): 187-192. https://doi.org/10.1007/s00128-011-0485-7.

[123] Nirmal-Kumar, J. I., Soni, H., Kumar, R. N. (2007): Characterization of heavy metals in vegetables using inductive coupled plasma analyzer (ICPA). - Journal of Environmental Science \& Management 11(3): 75-79. https://doi.org/10.4314/jasem.v11i3.55131.

[124] Norouzi, M., Mansouri, B., Hamidian, A. H., Ebrahimi, T., Kardoni, F. (2012): Comparison of the metal concentrations in the feathers of three bird species from southern Iran. - Bulletin of Environmental Contamination \& Toxicology 89(5): 10821086. https://doi.org/10.1007/s00128-012-0798-1. 
[125] Nowak, J., Szymczak, J., Słobodzian, T. (2003): The test of qualification 50\% threshold of toxicity of doses different heavy metals for soil phosphatases. - Zeszyty Problemowe Postępów Nauk Rolniczych 492: 241-248.

[126] Obiri, S. (2007): Determination of heavy metals in water from boreholes in Dumasi in the Wassa West District of western region of Republic of Ghana. - Environmental Monitoring \& Assessment 130(1-3): 455-463. https://doi.org/10.1007/s10661-006-9435y.

[127] Ochieng, E. Z., Lalah, J. O., Wandiga, S. O. (2008): Water quality and trace metal distribution in a pristine Lake in the Lake basin in Kenya. - Bulletin of Environmental Contamination \& Toxicology 80(4): 362-368. https://doi.org/10.1007/s00128-008-93722.

[128] Ochieng, E. Z., Lalah, J. O., Wandiga, S. O. (2009): Anthropogenic sources of heavy metals in the Indian Ocean coast of Kenya. - Bulletin of Environmental Contamination \& Toxicology 83(4): 600-607. https://doi.org/10.1007/s00128-009-9807-4.

[129] Padovan, A., Munksgaard, N., Alvarez, B., McGuinness, K., Parry, D., Gibb, K. (2012): Trace metal concentrations in the tropical sponge Spheciospongia vagabunda at a sewage outfall: synchrotron X-ray imaging reveals the micron-scale distribution of accumulated metals. - Hydrobiologia 687(1): 275-288. https://doi.org/10.1007/s10750-011-0916-9.

[130] Page, V., Feller, U. (2005): Selective transport of zinc, manganese, nickel, cobalt and cadmium in the root system and transfer to the leaves in young wheat plants. - Annals of Botany 96(3): 425-434. https://doi.org/10.1093/aob/mci189.

[131] Pathak, P. N., Choppin, G. R. (2009): Effects of pH, ionic strength, temperature and complexing anions on the sorption behaviour of cobalt on hydrous silica. - Soil \& Sediment Contamination 5(18): 590-602. https://doi.org/10.1080/15320380903085709.

[132] Peca, L., Kós, P. B., Máté, Z., Farsang, A., Vass, I. (2008): Construction of bioluminescent cyanobacterial reporter strains for detection of nickel, cobalt and zinc. FEMS Microbiology Letters 289(2): 258-264. https://doi.org/ 10.1111/j.15746968.2008.01393.x.

[133] Pietrodangelo, A., Pareti, S., Perrino, C. (2014): Improved identification of transition metals in airborne aerosols by SEM-EDX combined backscattered and secondary electron microanalysis. - Environmental Science \& Pollution Research 21(6): 4023-4031. https://doi.org/10.1007/s11356-013-2261-1.

[134] Pulgarín, J. A., Bermejo, L. F., Durán, A. C. (2013): Fast simultaneous determination of traces of $\mathrm{Cu}(\mathrm{II})$ and $\mathrm{Co}(\mathrm{II})$ in soils and sediments with the luminol/perborate chemiluminescent system. - Environmental Monitoring \& Assessment 185(1): 573-580. https://doi.org/10.1007M0661-012-2576-2.

[135] Qiu, W., Zheng, Y. (2009): Removal of lead, copper, nickel, cobalt, and zinc from water by a cancrinite-type zeolite synthesized from fly ash. - Chemical Engineering Journal 145: 483-488. https://doi.org/10.1016/j.cej.2008.05.001.

[136] Ramani, S., Dragun, Z., Kapetanović, D., Kostov, V., Jordanova, M., Erk, M., HajrulaiMusliu, Z. (2014): Surface water characterization of three rivers in the lead/zinc mining region of northeastern Macedonia. - Archives of Environmental Contamination \& Toxicology 66(4): 514-528. https://doi.org/10.1007/s00244-014-0012-z.

[137] Rancelis, V., Cesniene, T., Kleizaite, V., Zvingila, D., Balciuniene, L. (2012): Influence of cobalt uptake by Vicia faba seeds on chlorophyll morphosis induction, SOD polymorphism, and DNA methylation. - Environmental Toxicology 27(1): 32-41. https://doi.org/10.1002/tox.20609.

[138] Rashed, M. N. (2001): Monitoring of environmental heavy metals in fish from Nasser Lake. - Environment International 27(1): 27-33. https://doi.org/10.1016/S01604120(01)00050-2.

[139] Regulation of the Polish Minister of the Environment of 26 January (2010): On the on reference values for various substances in the air. - Dziennik Ustaw (Official Journal) 16 poz. 87. 
[140] Regulation of the Polish Minister of the Environment of 18 November (2014): On the conditions to be met when sewage into water or soil and on substances particularly harmful to the aquatic environment (as amended). - Dziennik Ustaw (Official Journal) poz. 1800.

[141] Regulation of the Polish Minister of the Environment of 21 December (2015): On the criteria and method of evaluation of groundwater. - Dziennik Ustaw (Official Journal) poz. 85.

[142] Regulation of the Polish Minister of the Environment of 21 July (2016): On the classification of the status of surface waters and environmental quality standards for priority substances. - Dziennik Ustaw (Official Journal) poz. 1187.

[143] Regulation of the Polish Minister of the Environment of 1 September (2016): On the manner of conducting the assessment of contamination of the surface of the earth. Dziennik Ustaw (Official Journal) poz. 1395.

[144] Rizzio, E., Bergamaschi, G., Profumo, A., Gallorini, M. (2001): The use of neutron activation analysis for particle size fractionation and chemical characterization of trace elements in urban air particulate matter. - Journal of Radioanalytical and Nuclear Chemistry 248(1): 21-28. https://doi.org/10.1023/A: 1010605519848.

[145] Rognerud, S., Dauvalter, V. A., Fjeld, E., Skjelkvåle, B. L., Christensen, G., Kashulin, N. (2013): Spatial trends of trace-element contamination in recently deposited lake sediment around the Ni-Cu smelter at nikel, Kola Peninsula, Russian Arctic. - AMBIO 42(6): 724736. https://doi.org/10.1007/s13280-013-0384-8.

[146] Rong, L., Xun-Liu, H., Zi-Tao, J. (2008): Determination of trace amounts of cobalt in foods by polymer-phase fluorophotometry with thiamine. - European Food Research \& Technology 227(1): 111-116. https://doi.org/10.1007/s00217-007-0699-4.

[147] Ruta, L., Paraschivescu, C., Matache, M., Avramescu, S., Farcasanu, I. C. (2010): Removing heavy metals from synthetic effluents using "kamikaze" Saccharomyces cerevisiae cells. - Applied Microbiology \& Biotechnology 85(3): 763-771. https://doi.org/10.1007/s00253-009-2266-3.

[148] Ryuko, S., Ma, Y., Ma, N., Sakaue, M., Kuno, T. (2012): Genome-wide screen reveals novel mechanisms for regulating cobalt uptake and detoxification in fission yeast. Molecular Genetics \& Genomics 287(8): 651-662. https://doi.org/10.1007/s00438-0120705-9.

[149] Rzymski, P., Niedzielski, P., Klimaszyk, P., Poniedziałek, B. (2014): Bioaccumulation of selected metals in bivalves (Unionidae) and Phragmites australis inhabiting a municipal water reservoir. - Environmental Monitoring \& Assessment 186(5): 3199-3212. https://doi.org/10.1007M0661-013-3610-8.

[150] Saad, L., Parmentier, I., Colinet, G., Malaisse, F., Faucon, M. P., Meerts, P., Mahy, G. (2012): Investigating the vegetation-soil relationships on the copper-cobalt rock outcrops of Katanga (D. R. Congo), an essential step in a biodiversity conservation plan. Restoration Ecology 20(3): 405-415. https://doi.org/10.1111/j.1526-100X.2011.00786.x.

[151] Saaltink, R., Griffioen, J., Mol, G., Birke, M. (2014): Geogenic and agricultural controls on the geochemical composition of European agricultural soils. - Journal of Soils \& Sediments 14(1): 121-137. https://doi.org/10.1007/s11368-013-0779-y.

[152] Sandergaard, J. (2013): Dispersion and bioaccumulation of elements from an open-pit olivine mine in Southwest Greenland assessed using lichens, seaweeds, mussels and fish. - Environmental Monitoring \& Assessment 185(5): 7025-7035. https://doi.org/10.1007/s10661-013-3082-x.

[153] Sassman, S. A., Sarmah, A. K., Lee, L. S. (2007): Sorption of tylosin A, D, and A-aldol and degradation of tylosin A in soils. - Environmental Toxicology \& Chemistry 26(8): 1629-1635.

[154] Schmitt, C. J., Brumbaugh, W. G., May, T. W. (2009): Concentrations of cadmium, cobalt, lead, nickel, and zinc in blood and fillets of northern hog sucker (Hypentelium nigricans) from streams contaminated by lead-zinc mining: implications for monitoring. 
- Archives of Environmental Contamination \& Toxicology 56(3): 509-524. https://doi.org/10.1007/s00244-009-9288-9.

[155] Sheppard, P. R., Speakman, R. J., Ridenour, G., Glascock, M. D., Farris, C., Witten, M. L. (2007): Spatial patterns of tungsten and cobalt in surface dust of Fallon, Nevada. Environmental Geochemistry \& Health 29(5): 405-412. https://doi.org/10.1007/s10653007-9085-1.

[156] Singh, A. K., Cameotra, S. S. (2013): Efficiency of lipopeptide biosurfactants in removal of petroleum hydrocarbons and heavy metals from contaminated soil. - Environmental Science \& Pollution Research 20(10): 7367-7376. https://doi.org/10.1007/s113556-0131752-4.

[157] Singh, S. M., Sharma, J., Gawas Sakhalkar, P., Upadhyay, A. K., Naik, S., Pedneker, S. M., Ravindra, R. (2013): Atmospheric deposition studies of heavy metals in Arctic by comparative analysis of lichens and cryoconite. - Environmental Monitoring \& Assessment 185(2): 1367-1376. https://doi.org/10.1007/s10661-012-2638-5.

[158] Soylak, M., Cihan, Z., Yilmaz, E. (2012): Evaluation of trace element contents of some herbal plants and spices retailed in Kayseri, Turkey. - Environmental Monitoring \& Assessment 184(6): 3455-3461. https://doi.org/10.1007/s10661-011-2199-z.

[159] Soylak, M., Cihan, Z., Yilmaz, E. (2013): Heavy metal contents of organically produced, harvested, and dried fruit samples from Kayseri, Turkey. - Environmental Monitoring \& Assessment 185(3): 2577-2583. https://doi.org/10.1007M0661-012-2741-7.

[160] Söyüt, H., Beydemir, S. (2011): The impact of heavy metals on the activity of carbonic anhydrase from rainbow trout (Oncorhynchus mykiss) kidney. - Toxicology and Industrial Health 28(4): 296-305. https://doi.org/10.1177/0748233711410914.

[161] Stangl, G. I., Roth Maier, D. A., Kirchgessner, M. (2000): Vitamin B-12 deficiency and hyperhomocysteinemia are partly ameliorated by cobalt and nickel supplementation in pigs. - Journal of Nutrition 130(12): 3038-3044. https://doi.org/10.1093/jn/130.12.3038.

[162] Sukdeo, P., Pillay, S., Bissessur, A. (2012): A geochemical assessment of the middle and lower Mvoti river system, KwaZulu-Natal, South Africa. - Environmental Earth Sciences 66(2): 481-487. https://doi.org/10.1007/s12665-011-1256-9.

[163] Sun, X., Hao, H., Liu, Z., Zhao, F., Song, J. (2019): Tracing global cobalt flow: 19952015. - Resources, Conservation \& Recycling 149: 45-55. https://doi.org/10.1016/j.resconrec.2019.05.009.

[164] Swarnalatha, K., Letha, J., Ayoob, S. (2013): An investigation into the heavy metal burden of Akkulam-Veli Lake in south India. - Environmental Earth Sciences 68(3): 795806. https://doi.org/10.1007/s12665-012-1780-2.

[165] Swarup, D., Patra, R. C., Naresh, R., Kumar, P., Shekhar, P., Balagangatharathilagar, M. (2006): Lowered blood copper and cobalt contents in goats reared around lead-zinc smelter. - Small Ruminant Research 63(3): 309-313. https://doi.org/10.1016/j.smallrumres.2005.03.011.

[166] Sytschev, A. E., Vadchenko, S. G., Kamynina, O. K., Balikhina, E. N., Plashichina, I. G., Krylova, E. A., Grigor'yan, A. S., Toporkova, K., Konovalov, A. N., Selezneva, I. I. (2009): Porous materials from titanium-cobalt alloys for hybrid implants. - Bulletin of Experimental Biology \& Medicine 147(1): 52-58. https://doi.org/10.1007/s10517-0090428-z.

[167] Tappero, R., Peltier, E., Gräfe, M., Heidel, K., Ginder-Vogel, M., Livi, K. J. T., Rivers, M. L., Marcus, M. A., Chaney, R. L., Sparks, D. L. (2007): Hyperaccumulator Alyssum murale relies on a different metal storage mechanism for cobalt than for nickel. - New Phytologist 175(4): 641-654. https://doi.org/10.1111/j.1469-8137.2007.02134.x.

[168] Taugbol, O., Karlengen, I. J., Salbu, B., Aastveit, A. H., Harstad, O. M. (2010): Intravenous injections of cobalt reduce fatty acid desaturation products in milk and blood of lactating cows. - Journal of Animal Physiology \& Animal Nutrition 94(5): 635-640. https://doi.org/10.1111/j.1439-0396.2009.00950.x. 
[169] Tepe, Y. (2009): Metal concentrations in eight fish species from Aegean and Mediterranean Seas. - Environmental Monitoring \& Assessment 159(1-4): 501-509. https://doi.org/10.1007/s10661-008-0646-2.

[170] Thyssen, J. P., Jensen, P., Lidén, C., Julander, A., Jellesen, M. S., Menné, T., Johansen, J. D. (2011): Assessment of nickel and cobalt release from 200 unused hand-held work tools for sale in Denmark-Sources of occupational metal contact dermatitis? - Science of the Total Environment 409(22): 4663-4666. https://doi.org/10.1016/j.scitotenv.2011.07.056.

[171] Tiffany, M. E., Spears, J. W. (2005): Differential responses to dietary cobalt in finishing steers fed corn-versus barley-based diets. - Journal of Animal Science 83(11): 25802589. https://doi.org/10.2527/2005.83112580x.

[172] Trejo-Tapia, G., Jimenez-Aparicio, A., Rodriguesz-Monroy, M., De Jesus-Sanchez, A., Gutierrez-Lopez, G. (2001): Influence of cobalt and other microelements on the production of betalains and the growth of suspension cultures of Beta vulgaris. - Plant Cell Tissue \& Organ Culture 67(1): 19-23. https://doi.org/10.1023/A:1011684619614.

[173] Türkmen, M., Türkmen, A., Tepe, Y. (2011): Comparison of metals in tissues of fish from Paradeniz Lagoon in the coastal area of northern east Mediterranean. - Bulletin of Environmental Contamination \& Toxicology 87(4): 381-385. https://doi.org/10.1007/s00128-011-0381-1.

[174] Ulusoy, H. I., Gürkan, R., Demir, Ö., Ulusoy, S. (2012): Micelle-mediated extraction and flame atomic absorption spectrometric method for determination of trace cobalt ions in beverage samples. - Food Analytical Methods 5(3): 454-463. https://doi.org/10.1007/s12161-011-9268-3.

[175] Upadhyaya, D., Survaiya, M. D., Basha, S., Mandal, S. K., Thorat, R. B., Haldar, S., Goel, S., Dave, H., Baxi, K., Trivedi, R. H., Mody, K. H. (2014): Occurrence and distribution of selected heavy metals and boron in groundwater of the Gulf of Khambhat region, Gujarat, India. - Environmental Science \& Pollution Research 21(5): 3880-3890. https://doi.org/10.1007/s11356-013-2376-4.

[176] USEPA (2000): Radionuclides Notice of Data Availability Technical Support Document. Targeting and Analysis Branch Standards and Risk Management Division Office of Ground Water and Drinking Water United States Environmental Protection Agency. USEPA Office of Ground Water and Drinking Water in collaboration with USEPA Office of Indoor Air and Radiation United States Geological Survey. http://www.epa.gov/ogwdw/radionuclides/pdfs/regulation _radionuclides_rulemaking_techsupportdoc.pdf.

[177] Valera, P., Zavattari, P., Albanese, S., Cicchella, D., Dinelli, E., Lima, A., De Vivo, B. (2014): A correlation study between multiple sclerosis and type 1 diabetes incidences and geochemical data in Europe. - Environmental Geochemistry \& Health 36(1): 79-98. https://doi.org/10.100i/s10653-013-9520-4.

[178] Van der Ent, A., Baker, A. J. M., Reeves, R. D., Pollard, A. J., Schat, H. (2013): Hyperaccumulators of metal and metalloid trace elements: Facts and fiction. - Plant \& Soil 362(1): 319-334. https://doi.org/10.1007/s11104-012-1287-3.

[179] Waheed, S., Kamal, A., Malik, R. N. (2014): Human health risk from organ-specific accumulation of toxic metals and response of antioxidants in edible fish species from Chenab River, Pakistan. - Environmental Science \& Pollution Research 21(6): 44094417. https://doi.org/10.1007/s11356-013-2385-3.

[180] Wang, C. X., Zhu, W., Peng, A., Guichreit, R. (2001): Comparative studies on the concentration of rare earth elements and heavy metals in the atmospheric particulate matter in Beijing, China, and in Delft, the Netherlands. - Environment International 26(56): 309-313. https://doi.org/10.1016/S0160-4120(01)00005-8.

[181] Wang, F., Yao, J., Si, Y., Chen, H., Russel, M., Chen, K., Qian, Y., Zaray, G., Bramanti, E. (2010): Short-time effect of heavy metals upon microbial community activity. Journal of Hazardous Materials 173(1-3): 510-516. DOI: 10.1016/j.jhazmat.2009.08.114. 
[182] Wang, Y., Xie, W., Wang, D. (2007): Transferable properties of multi-biological toxicity caused by cobalt exposure in Caenorhabditis elegans. - Environmental Toxicology \& Chemistry 26(11): 2405-2412. https://doi.org/10.1897/06-646R1.1.

[183] Welp, G. (1999): Inhibitory effects of the total and water-soluble concentrations of nine different metals on the dehydrogenase activity of a loess soil. - Biology \& Fertility of Soils 30(1): 132-139. https://doi.org/10.1007/s003740050599.

[184] Wendling, L. A., Kirby, J. K., McLaughlin, M. J. (2009): Aging effects on cobalt availability in soils. - Environmental Toxicology \& Chemistry 28(8): 1609-1617. https://doi.org/10.1897/08-544.1.

[185] Werkenthin, M., Kluge, B., Wessolek, G. (2014): Metals in European roadside soils and soil solution - a review. - Environmental Pollution 189: 98-110. https://doi.org/10.1016/j.envpol.2014.02.025.

[186] Witte, C. P., Tiller, S. A., Taylor, M. A., Davies, H. V. (2002): Addition of nickel to Murashige and Skoog medium in plant tissue culture activates urease and may reduce metabolic stress. - Plant Cell Tissue \& Organ Culture 68(1): 103-104. https://doi.org/10.1023/A:1012966218478.

[187] Wu, Z., He, M., Lin, C. (2012): Environmental impacts of heavy metals (Co, Cu, Pb, Zn) in surficial sediments of estuary in Daliao River and Yingkou Bay (northeast China): concentration level and chemical fraction. - Environmental Earth Sciences 66(8): 24172430. https://doi.org/10.1007/s12665-011-1466-1.

[188] Wyszkowska, J., Wyszkowski, M. (2002): Effect of cadmium and magnesium on microbiological activity in soil. - Polish Journal of Environmental Studies 5(11): 585591.

[189] Wyszkowska, J., Wyszkowski, M. (2003): Effect of cadmium and magnesium on enzymatic activity in soil. - Polish Journal of Environmental Studies 12(4): 479-485.

[190] Wyszkowska, J., Kucharski, J., Kucharski, M. (2006): Nitrification process in soil contaminated with cobalt. - Polish Journal of Natural Science 20(1): 101-110.

[191] Wyszkowski, M., Sivitskaya, V. (2012): Changes in the content of organic carbon and available forms of macronutrients in soil under the influence of soil contamination with fuel oil and application of different substances. - Journal of Elementology 17(1): 139148. https://doi.org/10.5601/jelem.2012.17.1.12.

[192] Wyszkowski, M., Wyszkowska, J. (2007): The content of macroelements in spring barley (Hordeum vulgare L.) and thiers relations with the enzymatic activity of cobalt contaminated soil. - Proceeding of SECOTOX Conference and the International Conference on Environmental Management, Engineering, Planning and Economics 1: 181-186.

[193] Wyszkowski, M., Wyszkowska, J. (2009): The effect of contamination with cadmium on spring barley (Hordeum vulgare L.) and its relationship with the enzymatic activity of soil. - Fresenius Environmental Bulletin 18(7): 1046-1053.

[194] Wyszkowski, M., Wyszkowska, J., Radziemska, M. (2009): Macroelement content in field of oats (Avena sativa L.) cultivated on soils contaminated with copper, zinc, tin, cobalt and manganese. - Ecological Chemistry and Engineering, A 16(10): 1387-1394.

[195] Yabuki, L. N. M., Colaço, C. D., Menegário, A. A., Domingos, R. N., Kiang, C. H., Pascoaloto, D. (2014): Evaluation of diffusive gradients in thin films technique (DGT) for measuring $\mathrm{Al}, \mathrm{Cd}, \mathrm{Co}, \mathrm{Cu}, \mathrm{Mn}, \mathrm{Ni}$, and $\mathrm{Zn}$ in Amazonian rivers. - Environmental Monitoring \& Assessment 186(2): 961-969. https://doi.org/10.1007/s10661-013-3430-x.

[196] Yarsan, E., Yipel, M., Dikmen, B., Altintas, L., Ekici, H., Köksal, A. (2014): Concentrations of essential and non-essential toxic trace elements in wild boar (Sus. Scrofa L., 1758) tissues from Southern Turkey. - Bulletin of Environmental Contamination \& Toxicology 92(1): 10-14. https://doi.org/10.1007/s00128-013-1134-0.

[197] Zaharescu, D. G., Hooda, P. S., Soler, A. P., Fernandez, J., Burghelea, C. I. (2009): Trace metals and their source in the catchment of the high altitude Lake Respomuso, Central 
Pyrenees. - Science of the Total Environment 407(11): 3546-3553. https://doi.org/ 10.1016/j.scitotenv.2009.02.026.

[198] Zamani-Hargalani, F., Karbassi, A., Monavari, S. M., Abroomand Azar, P. (2014): A novel pollution index based on the bioavailability of elements: a study on Anzali wetland bed sediments. - Environmental Monitoring \& Assessment 186(4): 2329-2348. https://doi.org/10.1007/s10661-013-3541-4.

[199] Zereini, F., Alt, F., Messerschmidt, J., Wiseman, C., Feldmann, I., von Bohlen, A., Müller, J., Liebl, K., Püttmann, W. (2005): Concentration and distribution of heavy metals in urban airborne particulate matter in Frankfurt am Main, Germany. Environmental Science \& Technology 39(9): 2983-2989. https://doi.org/ 10.1021/es040040t.

[200] Zupančič, N., Skobe, S. (2014): Anthropogenic environmental impact in the Mediterranean coastal area of Koper/Capodistria, Slovenia. - Journal of Soils \& Sediments 14(1): 67-77. https://doi.org/10.1007M1368-013-0770-7. 